\title{
REVISION OF THE SOUTH TEMPERATE GENUS GLYPHOLOMA JEANNEL, WITH FOUR NEW SPECIES (COLEOPTERA: STAPHYLINIDAE: OMALIINAE)*
}

\author{
By Margaret K. Thayer and Alfred F. Newton, JR.
}

Museum of Comparative Zoology, Harvard University

Cambridge, Massachusetts 02138 U.S.A.

\section{INTRODUCTION}

The southern temperate silphid genus Glypholoma Jeannel was transferred to the staphylinid subfamily Omaliinae by Newton (1975), and Lathrimaeodes Scheerpeltz (originally placed in the Omaliinae) was then synonymized with it. Newton (op. cit.) also presented additional descriptive information, a new locality record, and some discussion of the affinities of Glypholoma within the Omaliinae. Since that time, four new species of the genus have come to our attention, including one from Australia which greatly enlarges the known range of Glypholoma (previously only parts of Chile and Argentina). The discovery of these new species and the availability of a wealth of material of the type species, pustuliferum Jeannel, for detailed study led to our decision to revise the genus.

\section{METHODS}

Measurements, made with an ocular micrometer in a Leitz binocular dissecting microscope, are defined as follows:

Length: measured in lateral view from front of (closed) mandibles to apex of abdomen (excluding genitalia if exserted, and attempting to estimate "normal" degree of contraction of abdomen).

Width: maximum body width, across closed elytra at widest point (usually near middle).

Head width: in dorsal view, maximum width including eyes.

Head length: measured along midline from anterior margin of labrum to level of centers of ocelli, viewed perpendicular to line of measurement.

\footnotetext{
*Published with the aid of a grant from the Museum of Comparative Zoology, Harvard University.

Manuscript received by the editor October 6, 1978.
} 
Antennal length: from constriction between scape and its basal articulatory process to apex of last antennal segment.

Ocellar diameter: measured antero-posteriorly in dorsal view.

Pronotal width: maximum width.

Pronotal length: along midline from base to apex, viewed perpendicular to line of measurement.

Elytral width: same as Width, above.

Elytral length: measured along suture from apex of scutellum to a line tangent to elytral apices.

Prosternal process length: measured along midline from a transverse tangent to the anterior margin of the procoxal cavities to apex of prosternal process.

Procoxal length: measured in ventral view between transverse tangents to anterior and posterior faces of procoxae.

Mesosternal length: along midline from anterior margin to apex of mesosternal process.

Mesosternal process length: along midline from transverse tangent to anterior margin of mesocoxal cavities to apex of mesosternal process.

Mesocoxal length: measured in ventral view between transverse tangents to anterior and posterior margins of mesocoxal cavities.

Mesosternal procoxal cavity length: along midline from anterior margin of mesosternum to a line connecting the posterior edges of the cavities.

Metasternal length: along midline between extremities of intercoxal processes.

Metasternal antecoxal sutures: measured from lateral limit to lateral limit.

Metasternal width: between posterolateral corners of metasternum.

Hind coxal length: lateral edge to posteromesal corner.

Hind femoral length: including trochanter, from posteromesal corner of coxa to most distal point of femur.

Hind tibial length: along mesal side (not including any spines or setae).

Hind tarsal length: from point of insertion of tarsus on tibia to tarsal apex, not including claws or empodial setae. The dividing line between the fourth and fifth hind tarsal segments was taken to be the point of insertion of the fifth segment on the fourth. 
Abdominal segments are numbered according to their morphological origin. (The first segment visible ventrally is therefore the third segment.)

Mean length and width are given for each species, \pm one standard deviation.

Preparation of specimens for scanning electron microscope pictures consisted of clearing heads, mouthparts, and prothoraces in hot $1 \mathrm{~N}$ potassium hydroxide, critical-point drying all parts except elytra, and coating with gold-palladium mixture. Cleared and dissected specimens of pustuliferum and rotundulum and of the aedeagi of other species were examined under dissecting and compound microscopes.

Drawings were made with the aid of a camera lucida attachment on a Leitz binocular dissecting microscope.

\section{ACKNOWLEDGEMENTS}

This study probably would not have come about were it not for S. B. Peck's extensive collecting in Chile and his kindly making this material available to us; he later generously provided us with a multitude of Australian specimens as well.

Specimens were borrowed from the following institutions (abbreviated in the text as indicated) and we extend our thanks to the curators involved for their cooperation in lending specimens.

CAS California Academy of Sciences, San Francisco, California, U.S.A. (D. H. Kavanaugh)

CNC Canadian National Collection, Ottawa, Ontario, Canada (J. M. Campbell)

MCZ Museum of Comparative Zoology, Harvard University, Cambridge, Massachusetts, U.S.A.

NMVM National Museum of Victoria, Melbourne, Victoria, Australia (A. Neboiss)

Specimens are also deposited in the following collections:

ANIC Australian National Insect Collection, Canberra, A.C.T., Australia

ANMT A. F. Newton, Jr. and M. K. Thayer, Cambridge, Massachusetts, U.S.A.

FMNH Field Museum of Natural History, Chicago, Illinois, U.S.A.

SBP S. B. Peck, Ottawa, Ontario, Canada 


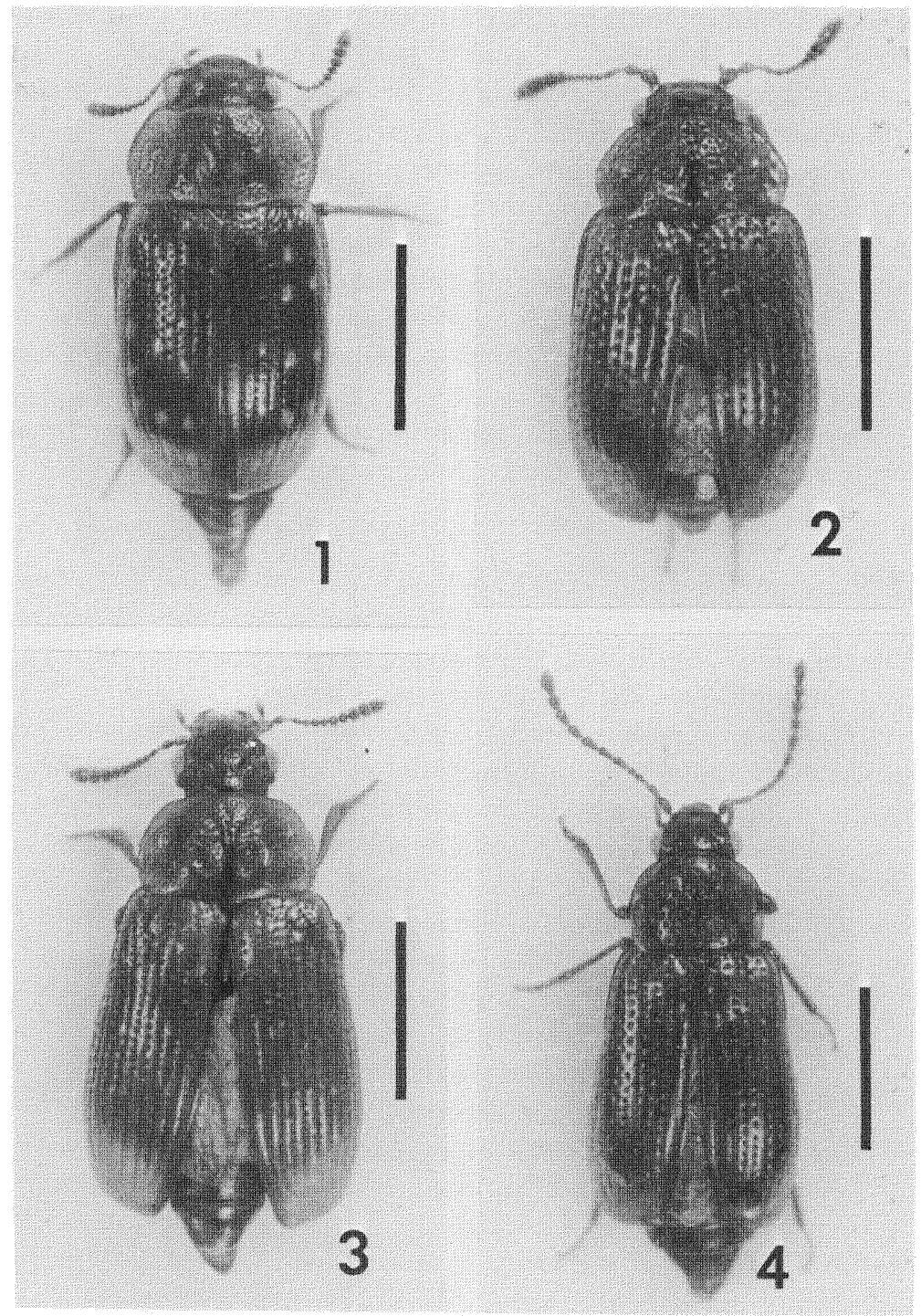

Figs. 1-4. Glypholoma spp. 1. G. pustuliferum. 2. G. pecki, holotype. 3. G. temporale, holotype. 4. G. tenuicorne, holotype. Scale lines $=1.0 \mathrm{~mm}$. 
The scanning electron microscope work done for this paper was made possible by National Science Foundation grants BMS-7502606 (J. F. Lawrence, principal investigator) and BMS-7412494 (SEM operating grant) with the superb technical assistance of E. Seling. We also thank L. H. Herman for calling our attention to the Klinger and Maschwitz paper, H. S. Dybas for reading and commenting upon the manuscript, and $\mathrm{N}$. Hinnebusch for typing the manuscript.

\section{Glypholoma Jeannel}

Glypholoma Jeannel, 1962: 482; Newton, 1975: 53. Type species: Glypholoma pustuliferum Jeannel, 1962: 483, by original designation and monotypy.

Lathrimaeodes Scheerpeltz, 1972: 58; (placed in synonomy by Newton, 1975: 54).

Type species: Lathrimaeodes pustulipenne Scheerpeltz, 1972: 59, by original designation and monotypy.

Diagnosis: Separable from other known Omaliinae by the excavate hind coxae, each elytron with eleven more or less distinct striae, male genital segment with a small "button" internally at the anterior end of sternite 9 , and visible dorsal pleural-coxal articulation in the

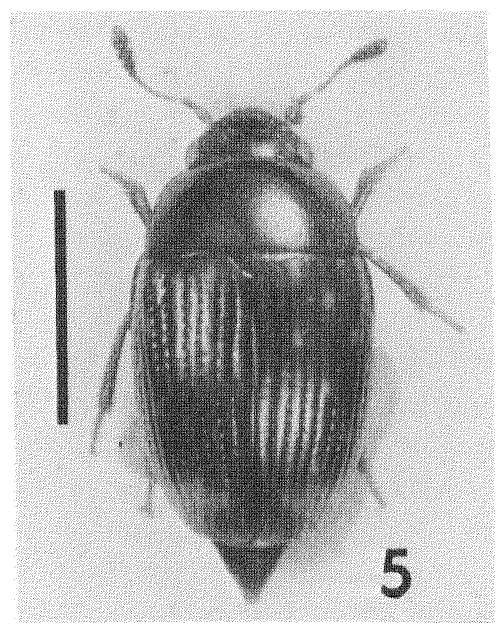

Fig. 5. Glypholoma rotundulum. Scale line $=1.0 \mathrm{~mm}$. 
prothorax. In addition, the combined presence of all of the following characters serves to distinguish Glypholoma from other Omaliinae. (Some other genera share one or a few of these characters with Glypholoma, but no other genus examined possesses all of these characters as Glypholoma does.)

1. Gular sutures widely separated, minimum separation equal to 0.12-0.18 times the head width.

2. Prothoracic pleural-sternal articulation present.

3. Procoxa with mesal articulating groove.

4. Mesosternal procoxal cavities long, $0.40-0.75$ times the total mesosternal length.

5. Hind femur relatively short, ranging from 0.92-1.05 times hind coxal length.

6. Deflexed lateral portion of elytron short, only $0.64-0.67$ times as long as total length of elytron (measured in lateral view).

7. Humeral margin of elytron serrulate.

8. Median lobe of aedeagus with membranous part of basal bulb allowing dorsal-ventral instead of lateral-lateral contraction and expansion.

9. Epistomal suture present and complete (although with or without median stem).

Description: Ovoid (narrower posteriorly) to more or less oblong in dorsal view, slightly to strongly convex dorsally in cross section. Sparsely pubescent to nearly glabrous on dorsal surface, widely spaced macrosetae on alternate intervals of elytra in a fairly characteristic pattern (pattern varies some among the species; see figs. 26, 29). Microsculpture lacking on dorsal surface of head, pronotum, and elytra. Length $2.1-3.5 \mathrm{~mm}$, width $1.0-1.5 \mathrm{~mm}$.

Head capsule about as in fig. 58, lacking postocular ridge, temples, and nuchal constriction except in temporale, which has temples and a lateral nuchal constriction (fig. 57). Head about 1.8 times as wide as long, about 0.58 times as long as pronotal length, with pair of distinct ocelli on dorsal surface (see especially fig. 6); no anteocellar grooves or pits. Epistomal suture with internal reinforcing ridge present, angulate or arcuate, with or without median stem. Antennae usually about 1 to 1.5 times as long as head width, varying from filiform (tenuicorne, about 2.2 times head width) to having a moderately developed club of about three to five segments; basal five to eight antennal segments glabrous except for a few 

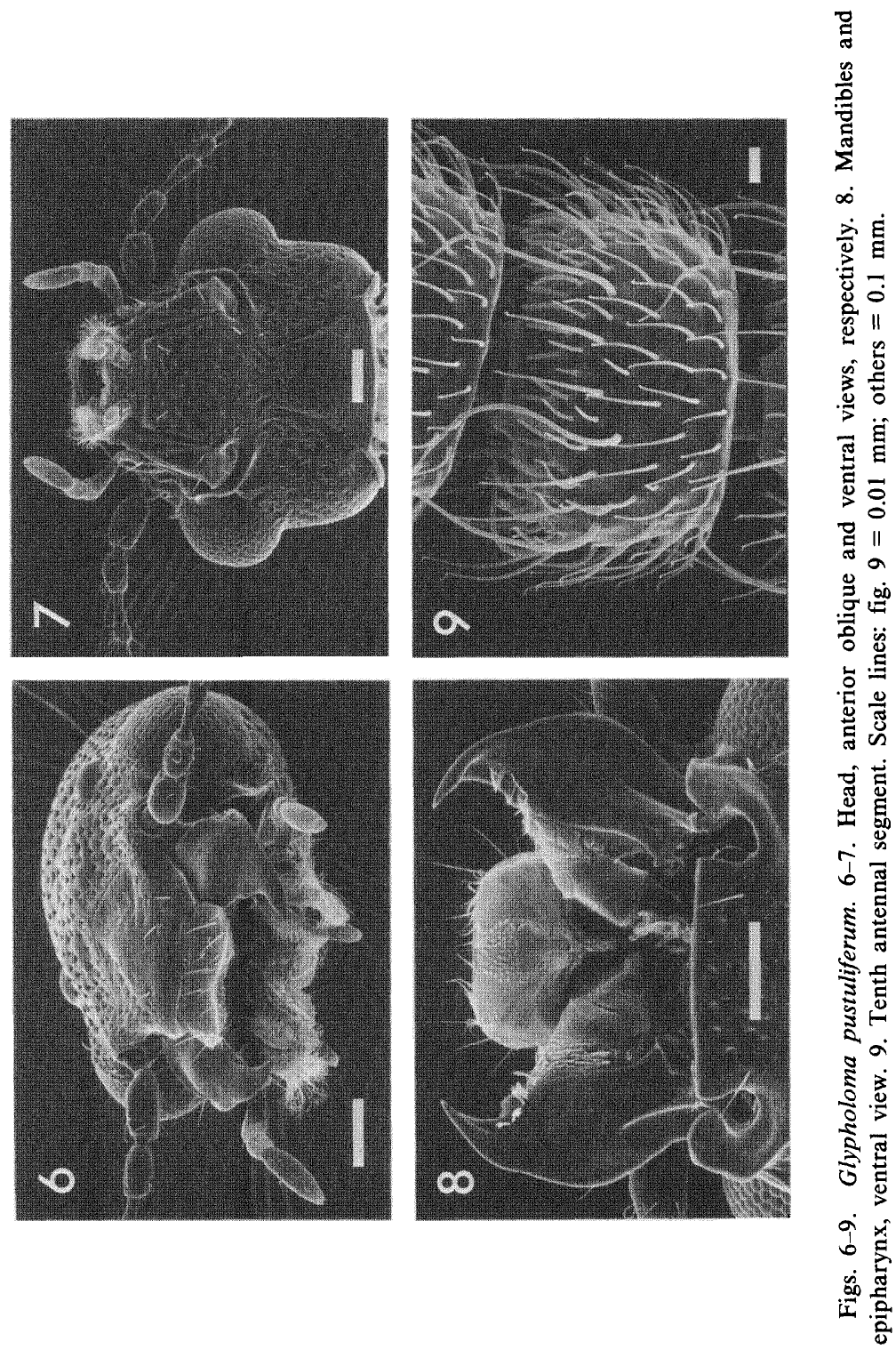

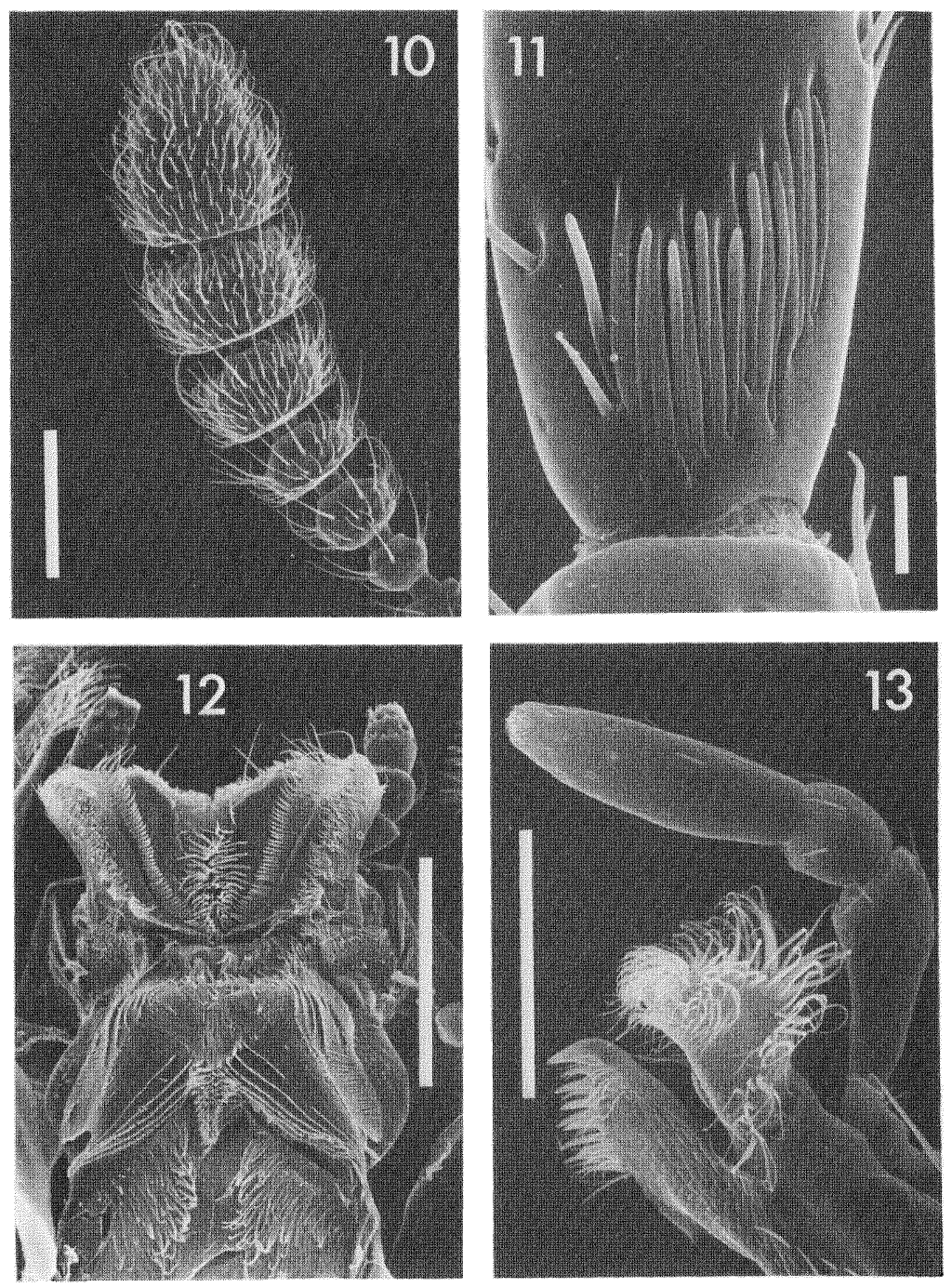

Figs. 10-13. Glypholoma pustuliferum. 10. Apical antennal segments. 11. Base of fourth maxillary palpal segment, external view. 12. Hypopharynx and labium, dorsal view. 13. Left maxilla, ventral view. Scale lines: fig. $11=0.01 \mathrm{~mm}$; others $=$ $0.1 \mathrm{~mm}$. 
scattered long setae. Apical antennal segments simple, without apical gutters or invaginations (see figs. 9, 10), with fairly dense short setae in addition to scattered long setae (see fig. 10, compare basal segments, fig. 7).

Labrum transverse, narrowly rectangular to slightly bilobed anteriorly, ventrally as in fig. 8. Mandible (of pustuliferum and rotundulum, at least) without preapical teeth, with a medial setose area about midway from base to apex and a well-developed molar lobe (see figs. 8, 14-17). Molar lobe apparently articulating dorsally and ventrally with mediobasal area of mandible proper. Maxilla more or less as in fig. 13, the palp generally filiform with fourth (apical) segment $2.5^{\circ}$ to 5 times as long as third, a group of sensilla as in fig. 11 on its dorsolateral surface near the base. Hypopharynx (of pustuliferum and rotundulum, at least) about as in fig. 12. Labium apparently bilobed, with three-segmented palps arising from separate palpigers; segments of palp subequal in length and width (see fig. 7, also Newton, 1975, fig. 3). Mentum large and trapezoidal; gular sutures separate, their minimum separation 0.12 to 0.18 times the head width (see fig. 7).

Pronotum 1.5 to 1.8 times as wide as long, about 0.35 times as long as elytra; widest point variable, from posterior corners to just behind middle; with complete sharp lateral margins, explanate in at least basal half; lacking lateral foveae with internal pillars. Postcoxal process of pronotum acutely triangular, apparently a bar to coxal flexation (see figs. 18, 20). Prosternum with or without median longitudinal keel; prosternal intercoxal process extending one-half to two-thirds of the (antero-posterior) length of the procoxae. Procoxa with external longitudinal keel and mesal transverse articulating groove (see figs. 18-21). Protrochantin exposed, shorter than postcoxal pronotal process, dorsal pleural-coxal (trochantinal-coxal) articulation visible, pleural-sternal articulation present (the last possibly absent in tenuicorne), as in fig. 20 .

Mesosternum 0.5 to 0.6 times as long as metasternum, with a nearly acute process (except in rotundulum, see figs. 35,37 ) extending between the mesocoxae for four to seven tenths of their length (figs. 34, 36). Mesosternal process not medially longitudinally carinate. Anterior part of mesosternum with cavities for reception of procoxae 0.4 to 0.75 times as long as whole mesosternum. 

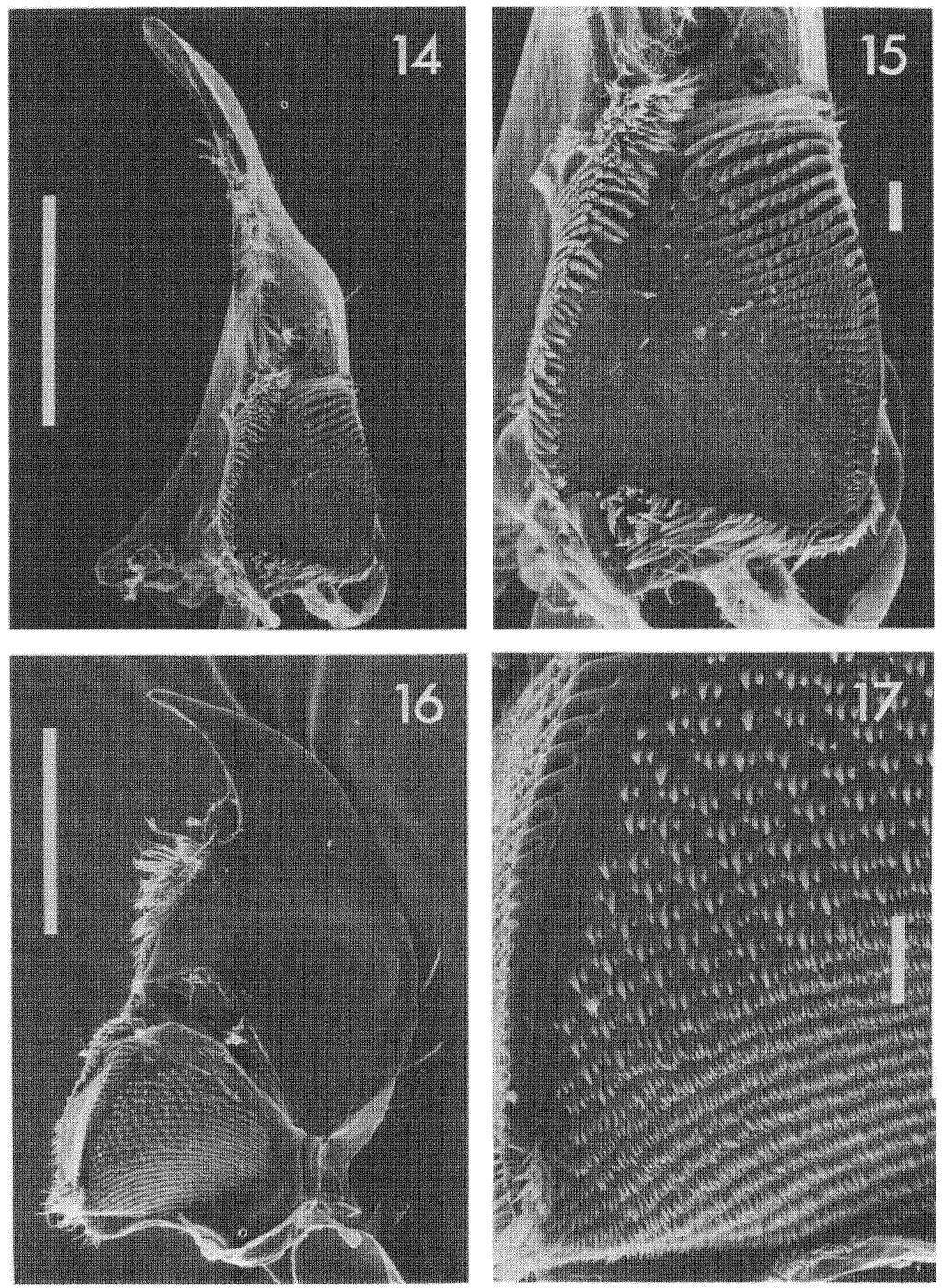

Figs. 14-17. Glypholoma pustuliferum, right mandible. 14-15. Mesal view, whole mandible and molar surface, respectively. 16-17. Dorsal view, whole mandible and part of mola, respectively. Scale lines: figs. $14,16=0.1 \mathrm{~mm}$; figs. $15,17=0.01 \mathrm{~mm}$. 

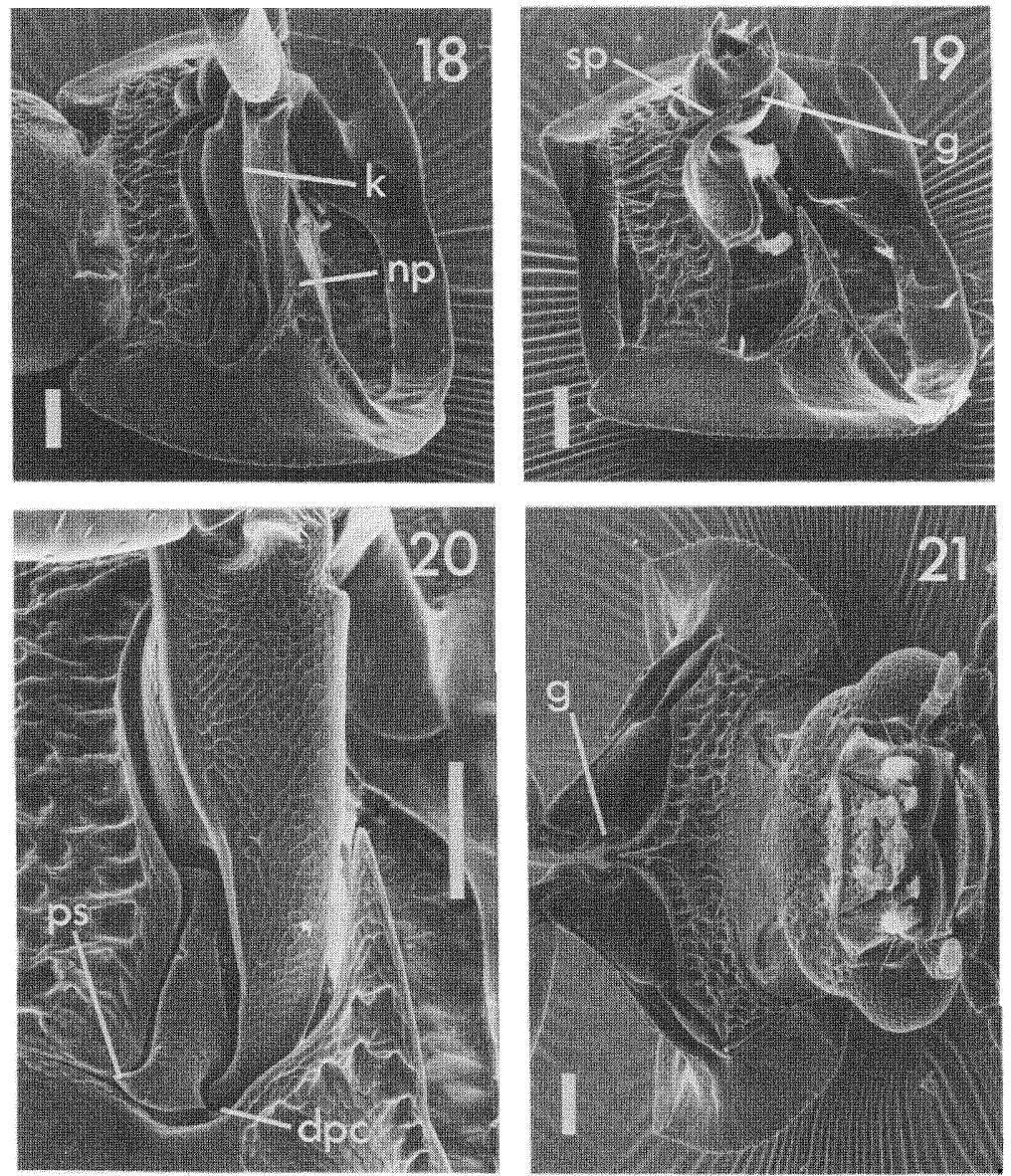

Figs. 18-21. Glypholoma pustuliferum. 18-19. Prothorax, ventrolateral view, with and without procoxa and trochantin, respectively. 20. Right procoxa and surrounding area, ventrolateral view, with coxa rotated anteriorly. 21. Prothorax and head, anteroventral view. $\mathrm{dpc}=$ dorsal pleural-coxal articulation; $\mathrm{g}=$ mesal articulating groove of coxa; $\mathrm{k}=$ external coxal keel; $\mathrm{np}=$ postcoxal process of pronotum; $\mathrm{ps}=$ pleural-sternal articulation; $\mathrm{sp}=$ prosternal intercoxal process. Scale lines $=0.1 \mathrm{~mm}$. 
Mesepisternal-mesepimeral suture present; mesosternal-pleural suture present posteriorly, but disappearing anteriorly, apparently with fusion of the two sclerites (except in tenuicorne, where it may be complete). Metasternum with short anterior process meeting mesosternal process between mesocoxae, short process with bifid apex between metacoxae, and antecoxal sutures as in fig. 59 (temporale only) or 60. Metacoxae excavate, i.e. with posterior face vertical and entire postero-ventral margin explanate (fig. 38).

Legs rather slender; tibiae only slightly, if at all, wider at apex than at base, usually with some small spines on the external surface (slightly fewer to slightly more than in fig. 23), meso- and metatibia generally with more spines than protibia, the sexes usually similar within each species. Hind coxa and femur subequal in length, hind tibia about 0.9 times as long as femur, hind tarsus $0.5-0.7$ times as long as tibia. All tarsi with five segments, hind tarsus with last segment one-third to two-thirds as long as first four together. Bisetose empodium between bases of tarsal claws (see fig. 39).

Elytra together about three-quarters as wide as long, each with eleven punctate striae (most clearly delimited in the middle section, more confused anteriorly and posteriorly) which are impressed between the punctures except in tenuicorne; eleventh stria (adjacent to epipleural keel) somewhat irregular. Macrosetae present on alternate intervals, associated in some species with raised pustules and/or spots; (except perhaps in tenuicorne?) intervals finely punctate between macrosetae (see figs. 26, 27, 29). Elytron with epipleural keel complete, serrulate in humeral region, intersecting with upturned lateral edge of elytron at about two-thirds the distance from elytral base to apex. Elytron covering abdomen through segment 5 or 6 , with apparent elytral-abdominal interlocking patches on the internal elytral surface just antero-mesal to the confluence of the epipleural keel and elytral edge (see figs. 30, 31) and on the lateral area of abdominal segment 3 (see fig. 46). (Whole complex seen in detail only in pustuliferum and rotundulum; elytral patch present in all species except possibly tenuicorne; because of the limited number of specimens available of three of the species, an exhaustive search for the abdominal patches could not be made.) Elytron with patch of small single or grouped teeth near apex of ventral surface (as in figs. 30, 32, 33). Wings covering abdomen through tergite 3 when folded, except in brachypterous individuals 

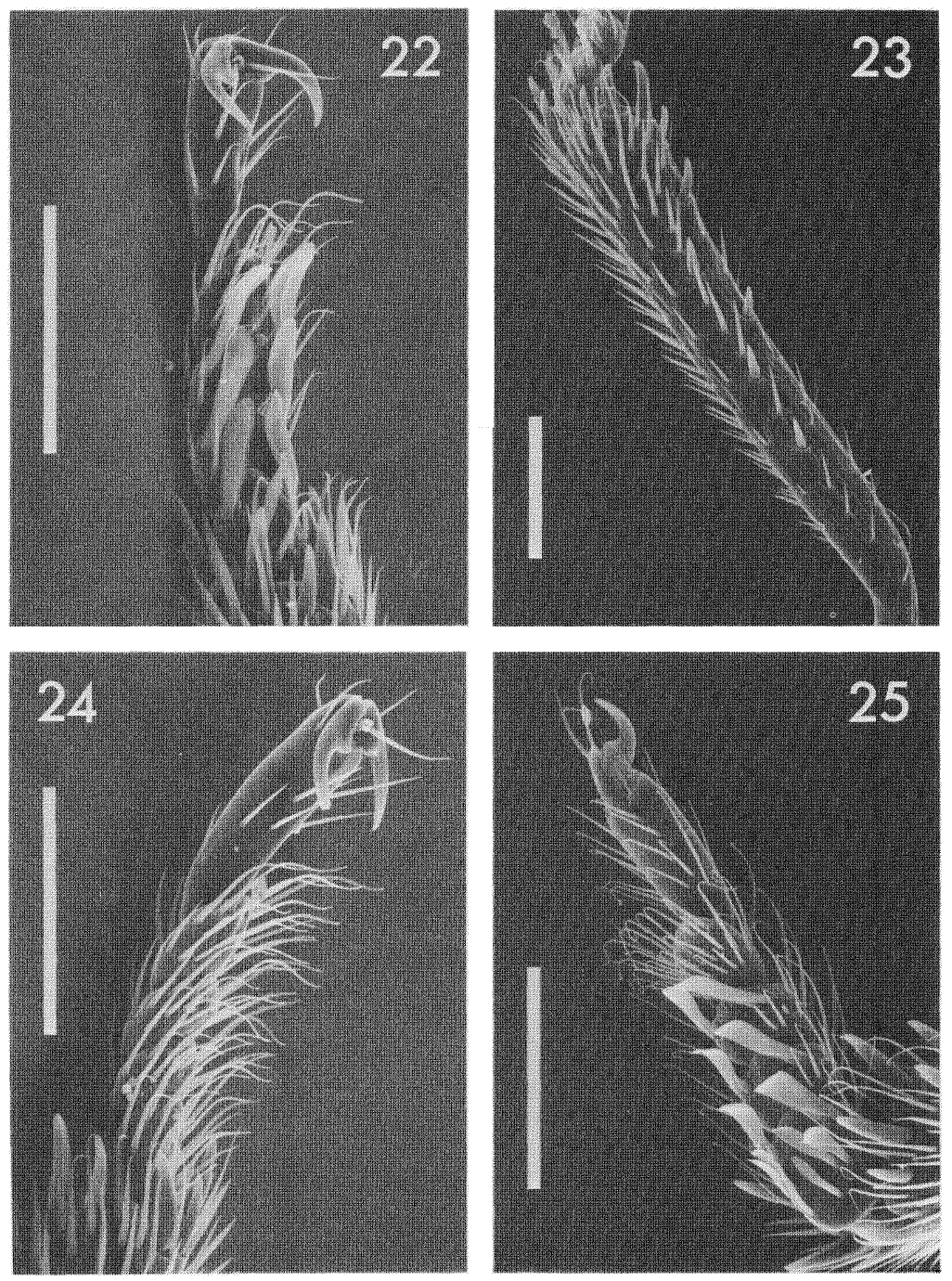

Figs. 22-25. Glypholoma spp., prolegs. 22-24. G. pustuliferum; 22, male tarsus, oblique ventral view; 23 , male left tibia, posterior view; 24 , female tarsus, oblique ventral view. 25. G. rotundulum, male tarsus, oblique ventral view. Scale lines $=0.1$ $\mathrm{mm}$. 

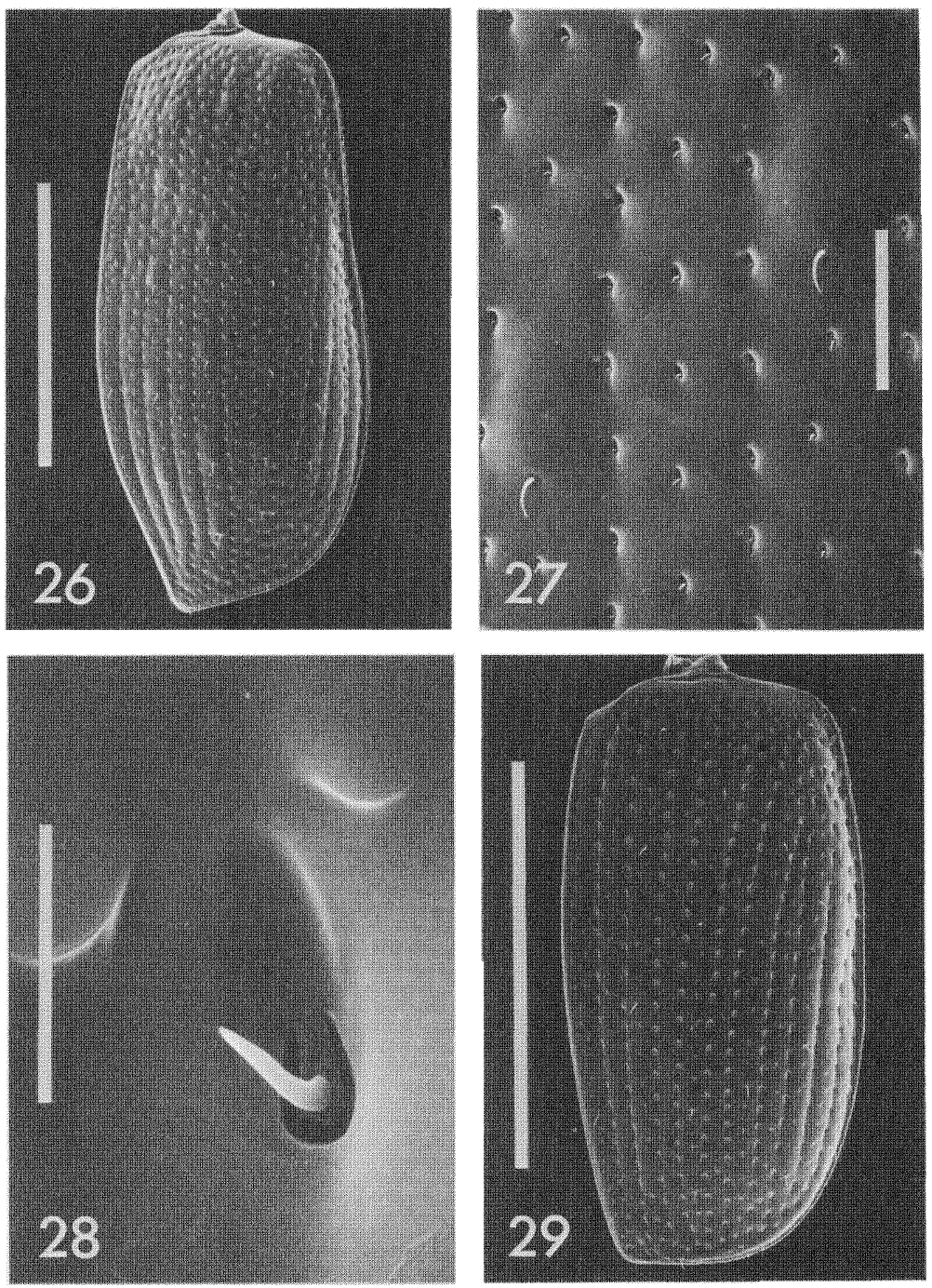

Figs. 26-29. Glypholoma spp. 26-28. G. pustuliferum, right elytron; 26, dorsolateral view; 27 , detail of fig. 26 , including two pustules; 28 , strial puncture (detail of fig. 26). 29. G, rotundulum, right elytron, dorsolateral view. Scale lines: figs. 26, $29=$ $1.0 \mathrm{~mm}$; fig. $27=0.1 \mathrm{~mm}$; fig. $28=0.01 \mathrm{~mm}$. 

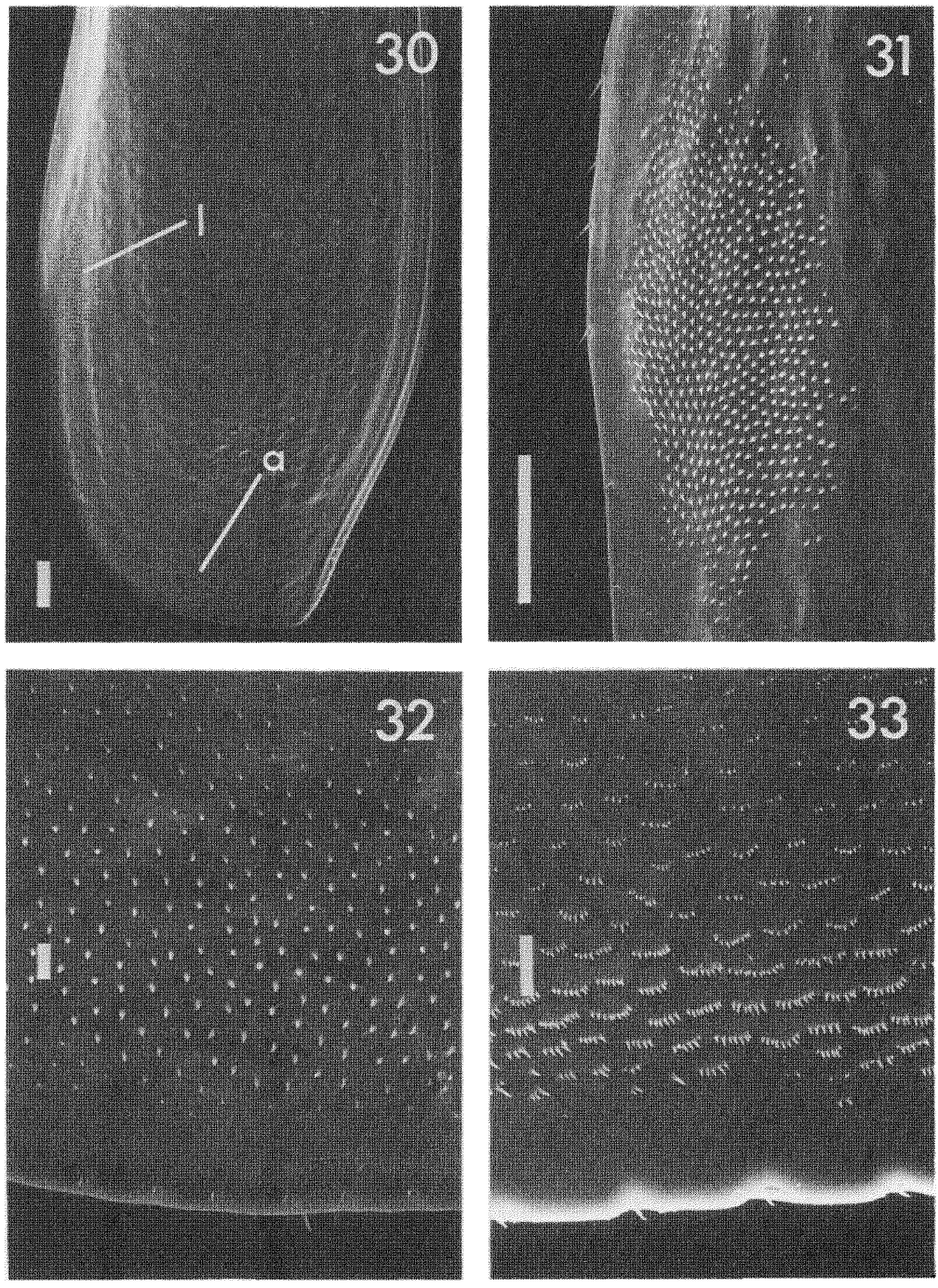

Figs. 30-33. Glypholoma spp., internal elytral surface. 30-32. G. pustuliferum; 30 , overall view; 31 , detail of lateral area ("1" in fig. 30); 32, detail of apex ("a" in fig. 30). 33. G. rotundulum, same view as fig. 32 . Scale lines: figs. $30,31=0.1 \mathrm{~mm}$; figs. $32,33=0.01 \mathrm{~mm}$. 
of rotundulum, in which the wings only reach the apex of tergite 2 and are not folded. Distinct anal flap present on wings of pustuliferum and rotundulum, probably in other species also. Folding pattern of fully-developed hind wing similar to that illustrated for Anthobium (=Eusphalerum) sorbi by Forbes (1926: fig. 33), the first transverse fold being a hinge by which the costal margin is turned about $90^{\circ}$. (In an individual, the hinges of the two wings usually form slightly different angles.)

Abdomen with most of segment 8 and part of genital segment exposed; first visible sternite is sternite 3 . Tergites 4 or 5 to 8 fairly well to well-sclerotized, spiracles located in tergites 4 or 5 to 8 , in membrane beside tergites 1 to 3 or 4 ; one pair of paratergites on each of segments 3 to 6 or 7, may be partly or entirely fused with sternites laterally (as almost complete fusion in fig. 47); tergite(s) 4 or 4 and 5 with paired patches of medially-directed microtrichia which cover about half to nearly all of the surface of the tergites (figs. 40-43); tergite 7 with an apical fringe ("palisade fringe" of some authors) as in fig. 45 . Intersegmental membranes with a brick wall pattern of irregular plates as in fig. 44 , some dorsal plates with posterior teeth as shown. Sternite 2 extending up around sides of abdomen slightly, but in tenuicorne appearing to be membranous, its limits therefore not determinable. Sternites 2 and 3 with small intimately associated intercoxal processes, more or less as in fig. 48, sternite 3 (at least in pustuliferum and rotundulum) with a transverse fold across its middle one-fourth to one-half about at posterior margin of intercoxal process (this area not visible in other species because of telescoping of abdomens). Sternite 3 without distinct coxal cavities, metacoxae simply protruding parallel to sternite's surface; at least in some species with a ridge near basal margin and, like sternites 4 to 5 or 6 , a curved ridge just inside each lateral margin. Sternite 8 with anterior median projection (see figs. 49, 61-65) associated with a gland system, similar to that described by Klinger and Maschwitz (1977). In at least three species (rotundulum, pecki, pustuliferum) gland reservoir extending anteriorly as far as anterior margin of segment 5.

Male: Peg setae apparently absent from trochanters, femora, and tibiae; first four segments of protarsus slightly broadened, spatulate setae in pairs on segments 1 to 3 of protarsus (figs. 22, 25), and singly on first two (possibly three in pecki) segments of mesotarsus 

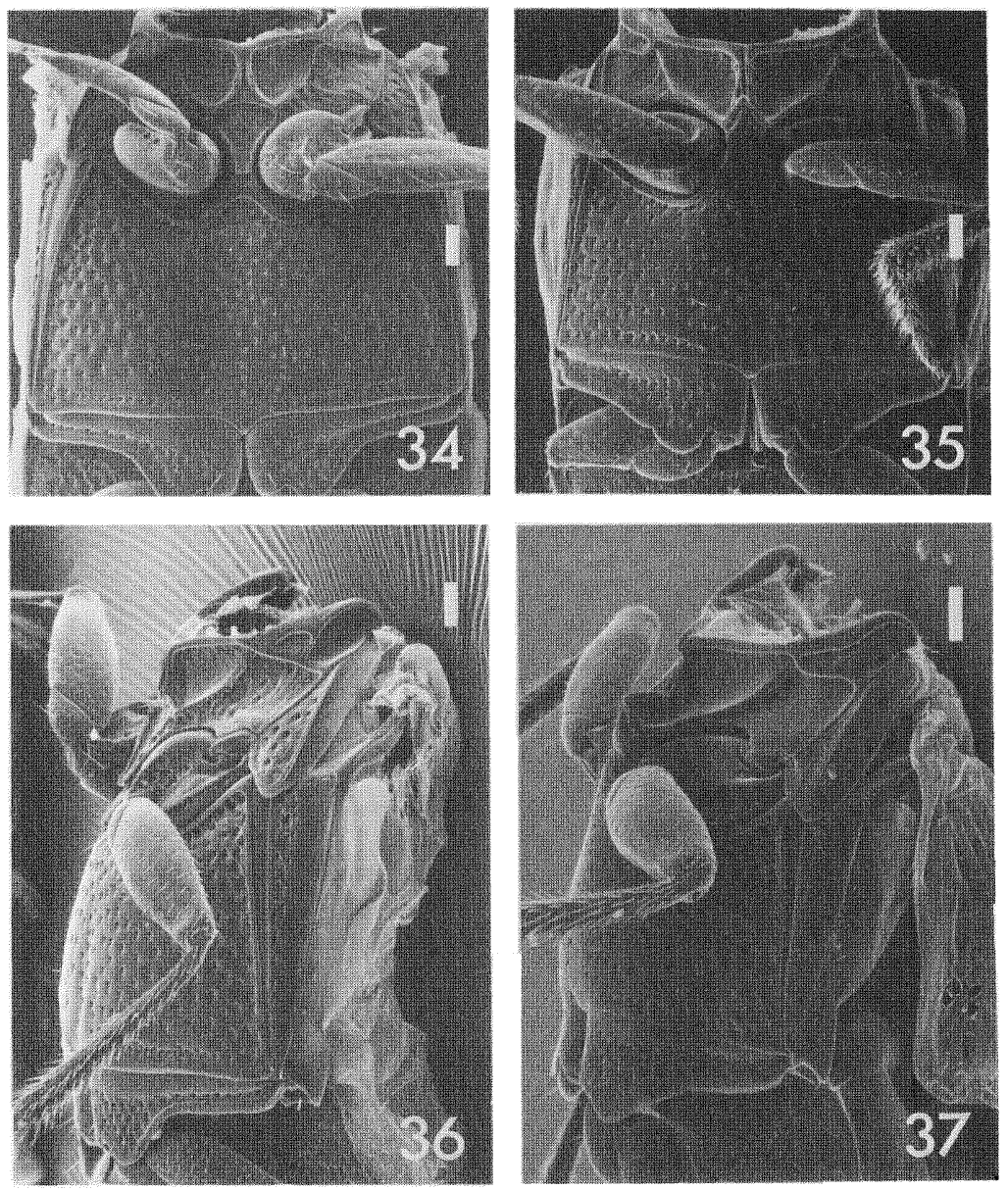

Figs. 34-37. Glypholoma spp., pterothorax. 34, 36. G. pustuliferum, ventral and oblique lateral views, respectively. 35,37 . G. rotundulum, ventral and oblique lateral views, respectively. Scale lines $=0.1 \mathrm{~mm}$. 

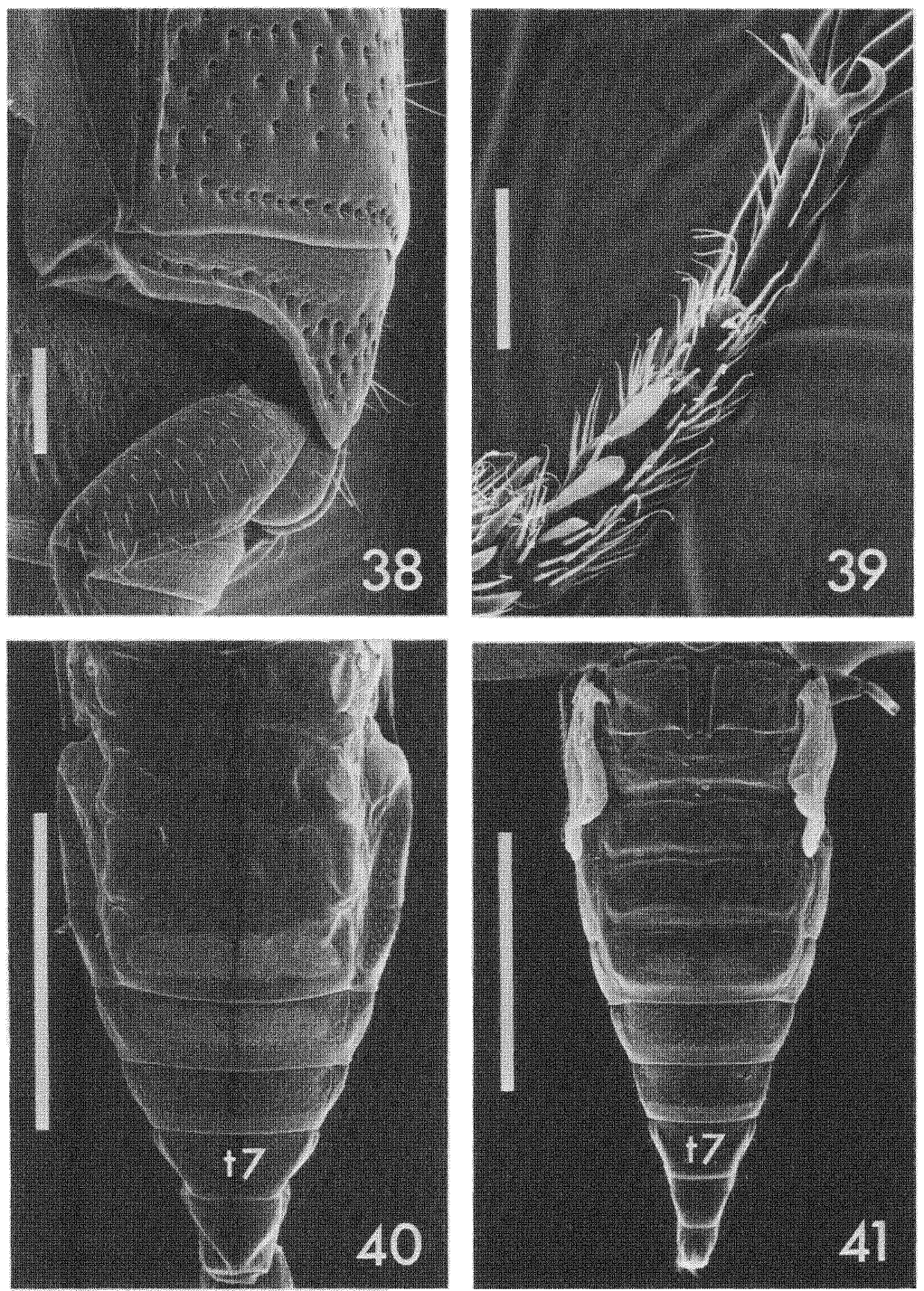

Figs. 38-41. Glypholoma spp. 38-40. G. pustuliferum; 38, metasternum and right metacoxa, lateral view; 39, male left mesotarsus, ventral view; 40, abdomen, dorsal view. 41. G. rotundulum, pterothorax and abdomcn, dorsal view. $\mathrm{t} 7=$ tergite 7. Scale lines: figs. $38,39=0.1 \mathrm{~mm}$; figs. $40,41=1.0 \mathrm{~mm}$. 

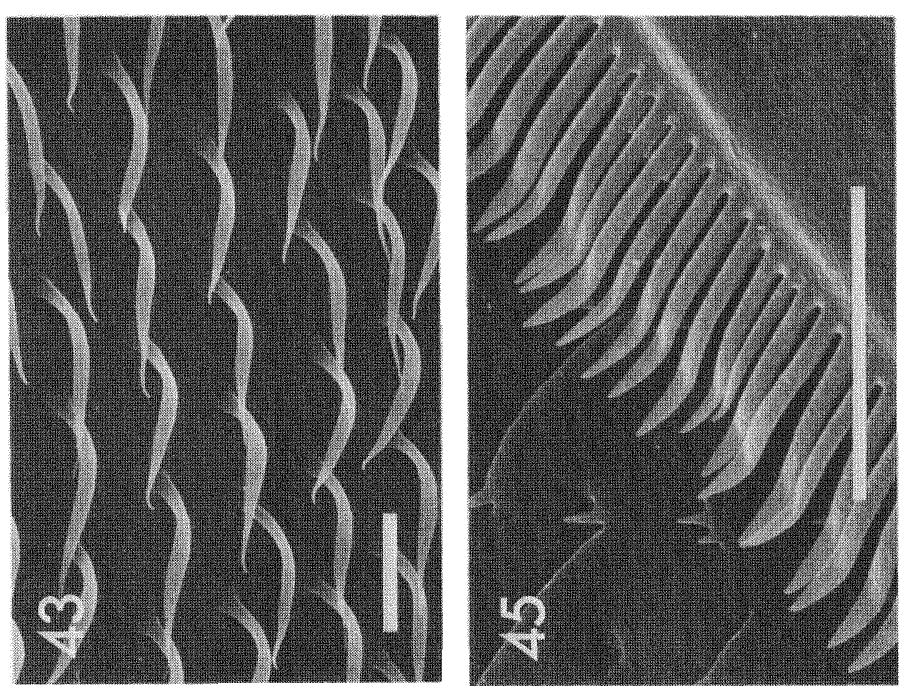

吾
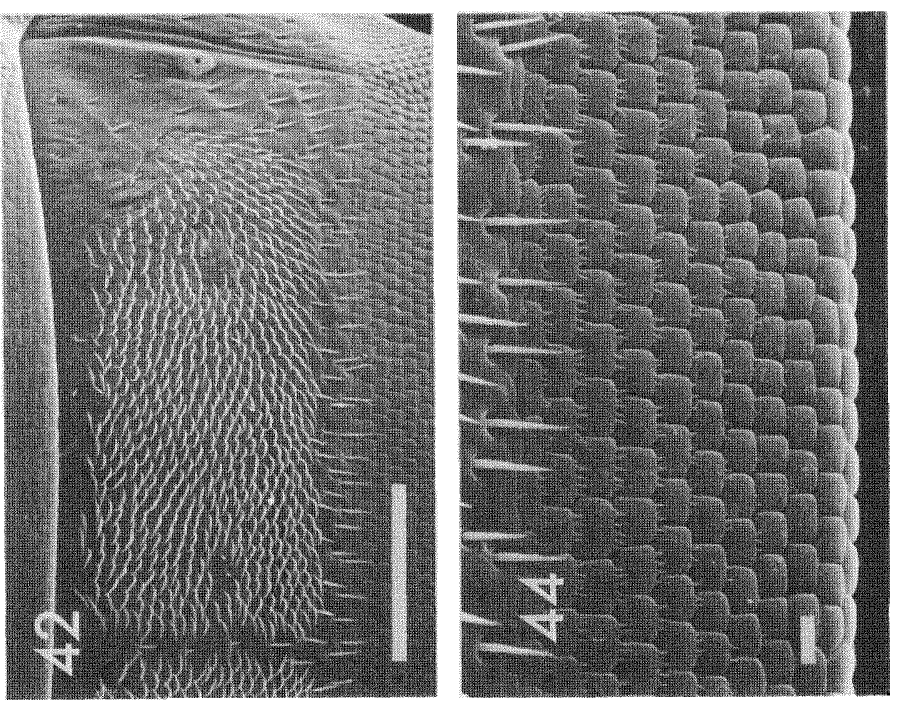

产

$\stackrel{\Xi}{\Xi}$

寸ㅎํ

ชิ

क क

苟苞

业

参

饮

㲅

द्व

总 흥

.

.

응

$\sum 0$

ช.

ชั

过岁

용

范

站密

क

ร

员

要

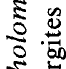

这

उ

ฯ

ช ฮี

宛泀

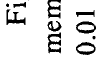



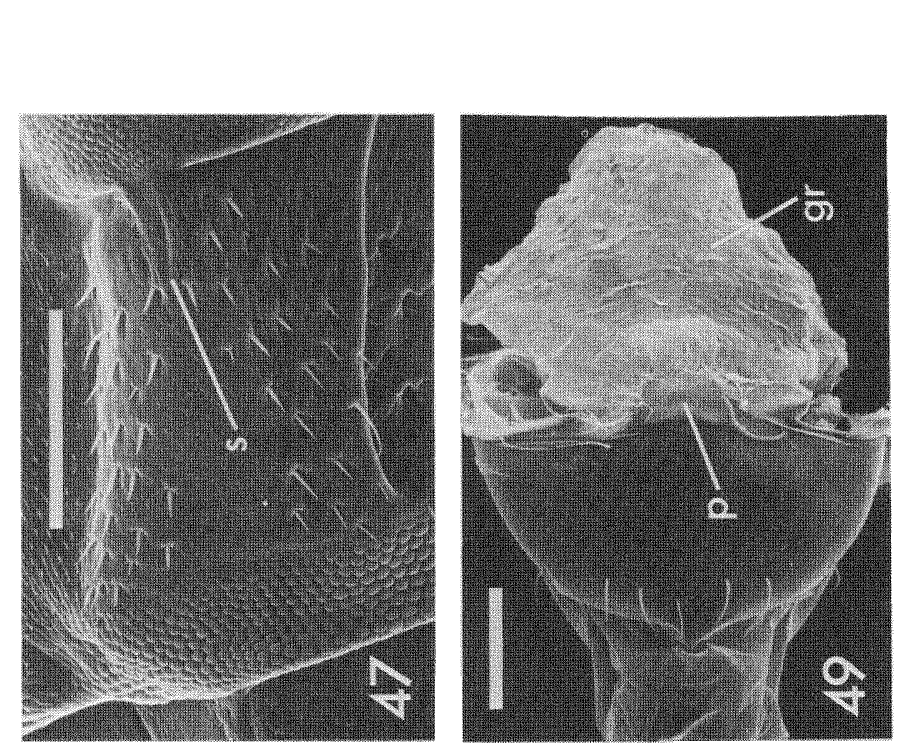

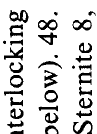

ส․

空焉总

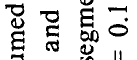

जे क्षा

芒氙 ؛

का త్ర 믐

.

的跑它

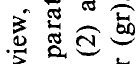

둥

जٓ

式芯芯

过

ले 屯 ठ

苞节品
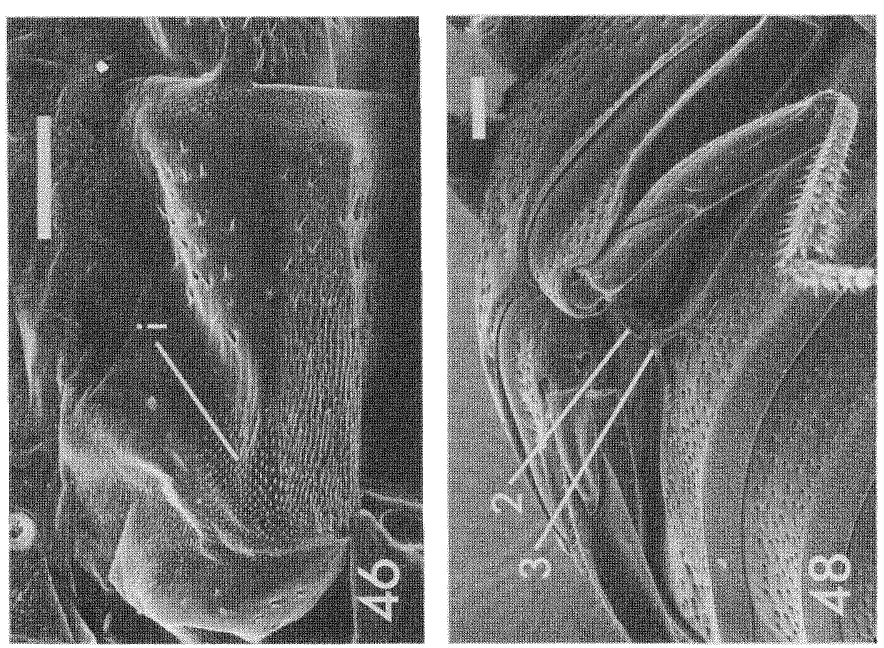

茄苏

离

+

نं

통

웅.

๙

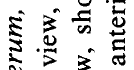

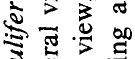

氙焉

के है क

ํ.

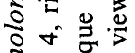

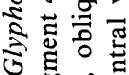

(5) हू :

虫

于े 可

+ $\Theta$

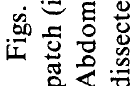


(see fig. 39). Genital segment with tergite 9 narrowly continuous across dorsal midline, tergite 10 short, sternite 9 attenuate, fairly well sclerotized in posterior one-third or so, only lightly sclerotized anteriorly, with a small cylindrical protuberance on internal surface near anterior end (see figs. 66-75). Aedeagus of general staphylinid type (median lobe with basal bulb, small dorsal median foramen, ventro-apical median orifice); parameral side of aedeagus facing dorsally within abdomen; small basal piece present as a more or less C- or U-shaped strap on dorsal side of basal bulb (often very lightly sclerotized and difficult to see); basal bulb of median lobe lightly sclerotized, with a membranous band around the abparameral side, presumably allowing dorsal-ventral bellows-like contractions; internal sac with dense armature of short, fine spines; apex of median lobe a finger-like projection, even with or slightly shorter than apices of parameres; parameres with or without subapical setae (see figs. 76-85).

Female: Pro- and mesotarsus without spatulate setae, as in fig. 24. Genitalia (based on pustuliferum and rotundulum, except as noted) about as in Newton, 1975, figs. 8-10: sclerotized spermatheca apparently absent, sternite 9 present, tergite 9 divided into two lateral sclerites, tergite $10 \mathrm{U}$-shaped; proximal gonocoxites separate, about half as long as distal gonocoxites; in all species in which females are known, distal gonocoxites separate, each bearing at its apex a short stylus with 1 (or 2?) long apical seta(e) and one or more subapical setae.

Immature stages unknown.

Range: Southern Chile and Argentina south to Tierra del Fuego; Victoria, Australia; see maps, figs. 50, 51.

\section{KEY TO THE SPECIES OF GLYPHOLOMA JEANNEL}

1. Antenna filiform (fig. 56); elytra without raised pustules; dorsal surface uniform in color; body form as in fig. $4 \ldots \ldots$. ......................... tenuicorne n.sp.

Antenna with gradual apical club (figs. 52-55); elytra with or without raised pustules; dorsal surface with various color markings; body form otherwise (figs. 1-3, 5) ........

2. Elytra with raised pustules on alternate intervals (fig. 26) .3 Elytra without raised pustules (fig. 29) .............4 
3. Postocular lobe present (fig. 57); metasternal antecoxal sutures long, about three-fourths the width of the metasternum (fig. 59); elytral pustules concolorous with surrounding area.. G. temporale n.sp.

Postocular lobe absent (fig. 58); metasternal sutures short, no more than about one-third the width of the metasternum (fig. 60 ); elytral pustules lighter in color than surrounding area .......................... pustuliferum Jeannel

4. Antennal segment 11 about $4 \times$ as long as segment 10 (fig. 52); mesosternal process a simple angulate projection between mesocoxae (cf. figs. 34,36 ); pronotum with lateral margins explanate, dorsal surface uneven; dark median spot on vertex of head, dark median streak on pronotum, no markings on elytra........................ pecki n.sp.

Antennal segment 11 not more than about $2.5 \times$ as long as segment 10 (fig. 55); mesosternal process an elevated pentagonal protuberance between mesocoxae (figs. 35, 37); pronotum evenly convex, not broadly explanate laterally; head and usually pronotum without markings, elytra with yellow spots on alternate intervals, sometimes with additional pale areas; usually brachypterous ...... G. rotundulum n.sp.

\section{Glypholoma pustuliferum Jeannel}

Glypholoma pustuliferum Jeannel, 1962: 483; Newton 1975: 53-54; Szymczakowski, 1976: 424.

Lathrimaeodes pustulipenne Scheerpeltz, 1972: 59. (Placed in synonymy by Newton, 1975: 54.)

With the characters of the genus as described above.

Moderately convex dorsally, shape as in fig. 1, various shades of brown in color: head darkest, reddish-brown to nearly black (with area anterior to epistomal suture the darkest part), basal two-thirds of elytra (except lateral margins) roughly concolorous with main part of head except for much lighter yellow pustules on alternate intervals; central area of pronotum similar to elytra or slightly lighter, with pronotal and elytral margins yellow to yellowishbrown, legs and dorsum of abdomen generally about the color of the central pronotal area. Ventral body surface usually reddishbrown, with lateral pronotal margins and deflexed portion of elytra 
paler. Some specimens (teneral?) are yellowish to reddish-brown, nearly unicolorous, with elytral pustules only slightly paler. Very short setae (similar to that in fig. 28) sparsely distributed over body surface, legs more densely setose, especially tibiae and tarsi. Length: $3.0 \pm 0.2 \mathrm{~mm}$ (2.6-3.5); width: $1.3 \pm 0.1 \mathrm{~mm}(1.1-1.5)(\mathrm{N}=55)$.

Head capsule as in figs. 6,7, and 58, epistomal suture with median stem (not always visible on surface). Antennal length about 1.1 times head width, first six antennal segments without dense pubescence, antennal club five-segmented, gradual (see fig. 54). Ocellar diameter about 0.095 times head width. Labrum shallowly emarginate anteriorly as in fig. 6. Maxillary palp with fourth segment about three times as long as third, the two approximately subequal in width.

Pronotum as in fig. 1, with several small shallow paramedian and lateral depressions; lateral margins explanate. Prosternum deeply pitted and rugose, but lacking microsculpture, and without median longitudinal carina (see figs. 18-21). Mesosternum with dense irregular microsculpture, cavities for reception of procoxae about half the length of the mesosternum; mesosternal process fairly narrow, blunt, extending seven-tenths of the way between mesocoxae (see figs. 34, 36). Metasternum convex with faint median longitudinal depression, surface without microsculpture but with short setae in large punctures (see fig. 36), antecoxal sutures short, extending only three-tenths the width of the metasternum (fig. 60). Protibia setose, with several small spines on outer surface (fig. 23), meso- and metatibia with slightly more spines. Hind tarsus sixtenths as long as hind tibia, fifth segment of hind tarsus two-thirds as long as first four together. Empodial setae subequal in length to tarsal claws.

Elytral striae impressed between punctures, intervals punctate and with short fine setae (in addition to macrosetae on alternate intervals; see figs. 26, 27). Pale pustules located anterior and adjacent to macrosetae. Angle formed by elytral apices at suture about $180^{\circ}$. Wings fully developed, with anal flap.

Abdomen with tergites 4 to 8 well sclerotized, spiracles located in tergites of these segments; paratergites separated anteriorly but not posteriorly from sternites on segments 4,5 and 6 (see fig. 47), apparently not separated from sternites on segments 3 and possibly 7. Tergites 4 and 5 with paired patches of medially-directed 
microtrichia as in figs. 40, 42, 43. Transverse fold on sternite 3 about one-fourth width of sternite. Sternite 8 with anterior projection as in figs. 49 and 61.

Male: Spatulate setae on protarsus as in fig. 22, three pairs on first segment, two pairs each on second and third segments, and on first two segments of mesotarsus as in fig. 39, three on first segment, two on second, only on anterior half of mesotarsal segments; genital segment and aedeagus as in figs. 66, 67, 84, 85 .

Female: Genitalia as illustrated by Newton (1975, figs. 8-10).

Distribution: see map, fig. 50. (Includes records from the literature and those listed below.)

Types: Glypholoma pustuliferum Jeannel. Holotype (sex unknown): CHILE: Aisén Province, Chile Chico [Museo Nacional de Historia Natural, Santiago, Chile]; not seen. Paratype as listed by Jeannel, 1962.

Lathrimaeodes pustulipenne Scheerpeltz. Holotype ( $\delta^{\star}$ ): ARgentina: Rio Negro Province, El Bolsón, Mt. Piltriquitron [Hungarian Natural History Museum, Budapest, Hungary]; not seen. Paratypes as listed by Scheerpeltz, 1972.

Material examined: CHILE: Malleco Prov.: $7 \mathrm{~km} \mathrm{~W} \mathrm{V.} \mathrm{Portales,}$ $1300 \mathrm{~m}, 23-24 . X I I .1976$, S. Peck (1) [SBP]; $15 \mathrm{~km} \mathrm{~W} \mathrm{V.} \mathrm{Portales,}$ $1650 \mathrm{~m}, 22-25 . X I I .1976$, S. Peck (2) [SBP]; $15 \mathrm{~km} \mathrm{~W}$ Victoria, 200 m, 28-30.XII.1976, S. Peck (2) [SBP]; 20 km E Manzanar (=30 km E Curacautin, nr. Malalcahuello), 1100 m, 19-31.XII.1976, S. Peck (106) [ANIC, ANMT, CNC, FMNH, MCZ, NMVM, SBP]; same locality, 1300-1400 m, 19-21.XII.1976, S. Peck (1) [SBP]; same locality, no elev., 19-25.XII.1976, S. Peck (16) [ANMT, CNC]; Talca Prov.: Alto Vilches, $1300 \mathrm{~m}, 10-13 . X I I .1976$, S. Peck (3) [ANMT, SBP]; Ñuble Prov.: Las Trancas, $70 \mathrm{~km}$ E Chillan, $1400 \mathrm{~m}$, 13-17.XII.1976 (some labeled $70 \mathrm{~km}$ SE Chillan $1300 \mathrm{~m}, 14-$ 17.XII), S. Peck (15) [ANMT, CNC, SBP]; Magallanes Prov.: Punta Arenas, Feb. 1906, R. Thaxter (6) [MCZ]; Cautin Prov.: 22 km E Temuco, VI-VII.1951, M. G. Smith (2) [CAS].

Habitat: Of the material examined, ecological data are available for most of the specimens collected by Peck. Twenty-eight specimens were collected at dung traps (three collections), 35 at carrion traps (five collections), 60 from litter under carrion left for several days (one collection), and one from mushrooms on a rotting stump (with litter and moss; one collection). Most of these collections were 
made in Nothofagus forest (also two specimens from NothofagusAraucaria forest, one from Araucaria forest), and several of the dung and carrion traps were set near streams (S. Peck, pers. comm.). Scheerpeltz (1972), whose records are mainly small series, reports this species (as Lathrimaeodes pustulipenne) primarily from ground litter in forests of Nothofagus, Libocedrus, and other trees, and also mentions one record from an old rabbit carcass in such a forest. These beetles seem to live in forest litter, but are strongly attracted to carrion and dung. Nothing is known about their feeding habits.

\section{Glypholoma temporale, new species}

With the characters of the genus as described above.

Moderately convex dorsally, shape as in fig. 3, with central areas of pronotum and elytra brown, their lateral margins and the elytral apices yellowish, head and dorsum of abdomen between these two colors, slightly reddish; venter of body darker than dorsum, legs slightly paler than head. Head and pronotum with pale scattered short fine setae, elytra glabrous between macrosetae, tibiae and tarsi fairly densely setose. Length: $2.9 \pm 0.1 \mathrm{~mm}$; width: $1.3 \pm 0.02 \mathrm{~mm}$ $(\mathrm{N}=6)$.

Head capsule as in fig. 57, epistomal suture angulate, lacking median stem, temples and lateral nuchal constriction present. Antennal length about 1.3 times head width, first four antennal segments without dense pubescence, apical segments broader than basal, but distinct club difficult to delimit (see fig. 53). Ocellar diameter about 0.09 times head width. Labrum slightly emarginate anteriorly. Maxillary palp with fourth segment about 2.5 times as long as third, slightly wider at middle than third.

Pronotum as in fig. 3, with very shallow paramedian and lateral depressions, lateral margins explanate. Prosternal surface finely rugose, without median longitudinal carina. Mesosternum similar to that of pustuliferum (figs. 34, 36), with microsculpture; cavities for reception of procoxae about two-fifths the length of the mesosternum, mesosternal process narrow, extending just over half way between mesocoxae. Metasternum convex, lacking microsculpture but with large punctures containing minute setae, antecoxal sutures long, extending three-fourths the width of the metasternum 
(fig. 59). Protibia setose, slightly fewer spines than in pustuliferum (cf. fig. 23), meso- and metatibia with more spines than protibia. Hind tarsus nearly seven-tenths as long as hind tibia, fifth segment of hind tarsus half as long as preceding four together. Empodial setae longer than tarsal claws.

Elytral striae impressed between punctures, intervals finely punctate. Pustules (concolorous with surrounding area) present on alternate intervals, anterior and adjacent to macrosetae. Angle formed by elytral apices at suture slightly less than $180^{\circ}$ (convex posteriorly). Wings fully developed.

Abdomen with tergites 5 to 8 well-sclerotized, spiracles located in tergites of these segments; paratergites clearly present and distinct on segments 4 to 6 , sutures between sternite and paratergites lacking on segment 3 and (perhaps) posteriorly on segment 7 . Tergites 4 and 5 with paired patches of medially-directed microtrichia, fairly similar to those of pustuliferum (cf. fig. 40). Sternite 8 with anterior projection as in fig. 63 .

Male: Spatulate setae in pairs on protarsal segments $1-3$, singly on mesotarsal segments 1 and 2, similarly to fig. 39, but exact number unknown; genital segment and aedeagus as in figs. 70, 71, 82,83 .

Distribution: see map (fig. 50).

Holotype: CHILE: Malleco Prov., 20 km E Manzanar, 1925.XII.76 S. Peck, $1100 \mathrm{~m}$, carrion + dung traps [MCZ].

Paratypes $(20,3 \%)$ : Same locality and date as holotype; no elevation or habitat data [ANMT, CNC, MCZ, SBP].

Habitat: In addition to the label data, the holotype was collected in moist Nothofagus forest near a stream (S. B. Peck, pers. comm.).

Etymology: This species name refers to the well-developed temples on the head.

Glypholoma pecki, new species

With the characters of the genus as described above.

Moderately convex dorsally, shape as in fig. 2, unicolorous yellowish-brown, except the following darker brown: spot on vertex of head between ocelli, median longitudinal line on pronotum, last three or four antennal segments, and third and fourth segments of 


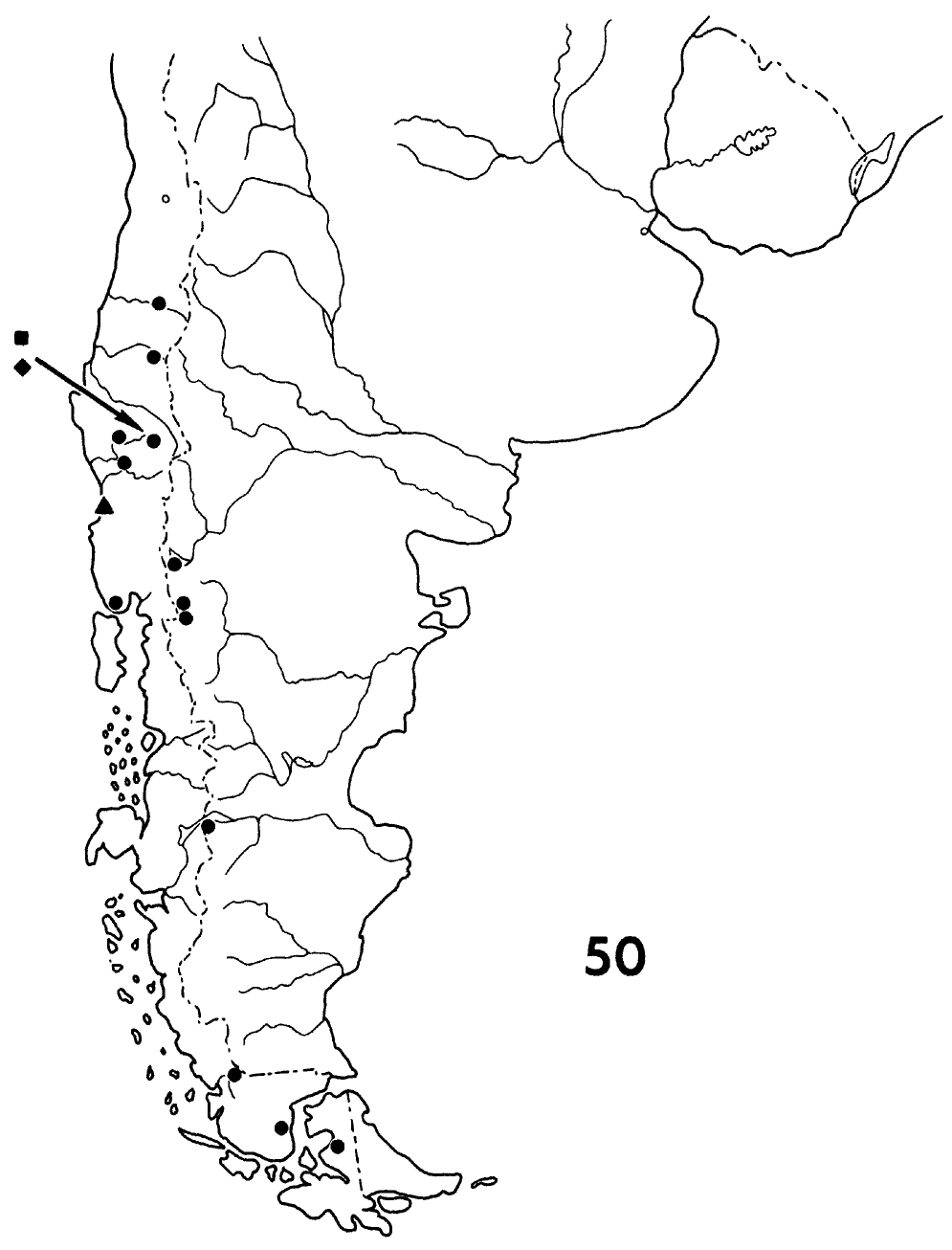

Fig. 50. Southern Chile and Argentina, showing locality records for South American Glypholoma spp.: G. pustuliferum, dots; G. temporale, diamond; G. pecki, square; G. tenuicorne, triangle. 
maxillary palps. Dorsal surface of head, pronotum, and elytra virtually glabrous except for elytral macrosetae. Length: $2.6 \mathrm{~mm}$; width: $1.2 \pm 0.03 \mathrm{~mm}$ (only two specimens seen).

Head capsule similar to that of pustuliferum (fig. 58), but eyes more prominent and epistomal suture lacking median stem. Antennal length about 1.3 times head width, first seven antennal segments without dense pubescence, antennal club three-segmented, apical segment four times as long as preceding segment (see fig. 52). Ocellar diameter about 0.08 times head width. Labrum approximately rectangular (anterior margin straight). Maxillary palp with fourth segment about 4.5 times as long as third, the two subequal in width.

Pronotum as in fig. 2, with shallow median and lateral depressions, lateral margins explanate. Prosternum coarsely punctate with median longitudinal carina. Mesosternum with dense microsculpture except on mesosternal process, cavities for reception of procoxae about half the length of the mesosternum, mesosternal process similar to that of pustuliferum (cf. figs. 34, 36), extending about two-thirds of the way between mesocoxae. Metathorax convex, without microsculpture, coarsely punctate with minute setae in punctures; antecoxal sutures short, extending one-fifth to one-fourth the width of the metasternum. Male protibia with a few external spines near apex, meso- and metatibia with a few more spines, female tibiae with fewer spines than male. Hind tarsus about two-thirds as long as hind tibia, fifth segment of hind tarsus threefifths as long as first four segments together. Empodial setae subequal in length to tarsal claws.

Elytral striae impressed between punctures, elytral intervals finely sparsely punctate between macrosetae on alternate intervals. Elytra without pale spots or raised pustules. Angle formed by elytral apices at suture slightly greater than $180^{\circ}$ (concave posteriorly). Wings fully developed.

Abdomen with tergites 5 to 8 well-sclerotized, spiracles located in tergites of these segments (possibly 4 also); sutures between sternite and paratergites apparently lacking on segments 3 to 7 . Tergites 4 and 5 with paired more or less rectangular patches of mediallydirected microtrichia, less extensive than those of pustuliferum (cf. fig. 40). Sternite 8 with anterior projection as shown in fig. 62 . 
Male: Spatulate setae in pairs on protarsus, number unknown, singly on first two or three segments of mesotarsus, number unknown; genital segment and aedeagus as in figs. $68,69,80,81$.

Distribution: See map (fig. 50).

Holotype ( ${ }^{*}$ ): CHILE: Malleco Prov., $20 \mathrm{~km} \mathrm{E} \mathrm{Manzanar,} 1100$ m, 19-25.XII.1976, S. Peck, malaise trap [MCZ].

Paratype ( $q$ ): Same data as holotype [CNC].

Habitat: Both specimens were collected in a malaise trap at the edge of moist Nothofagus forest (S. B. Peck, pers. comm.), but this species was absent from dung and carrion traps at the same locality which produced over 100 pustuliferum and one temporale.

Etymology: This species is named after Dr. Stewart B. Peck, who collected both types as well as most of the other specimens used in this study.

\section{Glypholoma tenuicorne, new species}

With the characters of the genus as described above.

Slightly convex dorsally, shape as in fig. 4, unicolorous light reddish-brown, head and pronotum dorsally with a few scattered setae, elytra glabrous except for macrosetae, tibiae and tarsi less densely setose than in other species. Length: $3 \mathrm{~mm}$; width: $1.2 \mathrm{~mm}$ (one specimen seen).

Head capsule generally similar to that of pustuliferum (fig. 58), but epistomal suture arcuate and lacking median stem. Antennal length about 2.2 times head width, first four antennal segments without dense pubescence, club lacking (see fig. 56). Ocellar diameter about 0.11 times head width. Labrum rectangular (anterior margin straight). Maxillary palp with fourth segment about 3.5 times as long as third, the two subequal in width.

Pronotum as in fig. 4, with shallow median and anterolateral depressions, lateral margins acute anteriorly, explanate posteriorly. Prosternum minutely rugose and sparsely punctate, without median longitudinal carina; pleural-sternal articulation possibly absent. Mesosternum with dense microsculpture, cavities for reception of procoxae about two-fifths the length of the mesosternum, mesosternal process similar to that of pustuliferum (figs. 34, 36), extending half the distance between mesocoxae; mesosternal-pleural 
suture possibly complete. Metasternum convex, without microsculpture, more finely punctate than pustuliferum (cf. fig. 34) and with most of the posterior half impunctate; antecoxal sutures short, extending one-fourth the width of metasternum. Protibia without spines externally, meso- and metatibia with only a few. Hind tarsus seven-tenths as long as hind tibia, fifth segment of hind tarsus onethird as long as first four segments together. Empodial setae subequal in length to tarsal claws.

Elytral striae not impressed between punctures, intervals impunctate except for macrosetae. Elytra without pale spots or raised pustules. Angle formed by elytral apices at suture slightly greater than $180^{\circ}$ (concave posteriorly). Wings fully developed.

Abdomen with tergites 4 to 8 well-sclerotized, spiracles in tergites of segments 4 (or possibly 3 ) to 8 ; paratergites clearly present and distinct on segments 4 to 6 , sutures between sternite and paratergites lacking on segment 3. (Structure of segment 7 uncertain.) Tergites 4 and 5 with paired patches of medially-directed microtrichia, patches slightly narrowed laterally but still occupying most of the width and (medially) the length of both tergites. Sternite 8 with anterior projection as in fig. 64 .

Male: Spatulate setae in pairs on protarsal segments 1-3, number unknown, present singly on anterior half of first two segments of mesotarsus, number unknown; genital segment and aedeagus as in figs. 72, 73, 76, 77.

Female unknown.

Distribution: See map (fig. 50).

Holotype ( ${ }^{\star}$ ): CHILE: Valdivia Prov., Corral, Dec. 1905, R. Thaxter [MCZ].

Etymology: The species name tenuicorne refers to the long slender antennae, apparently unique within the genus.

\section{Glypholoma rotundulum, new species}

With the characters of the genus as described above.

Very convex dorsally, shape as in fig. 5, reddish-brown to dark brown or occasionally almost black, elytra with small yellow spots on alternate intervals, a slightly larger yellow spot at each humerus, and usually a still larger subapical yellow patch on each elytron. Elytra sometimes with light areas laterally, apically, or basally (or 


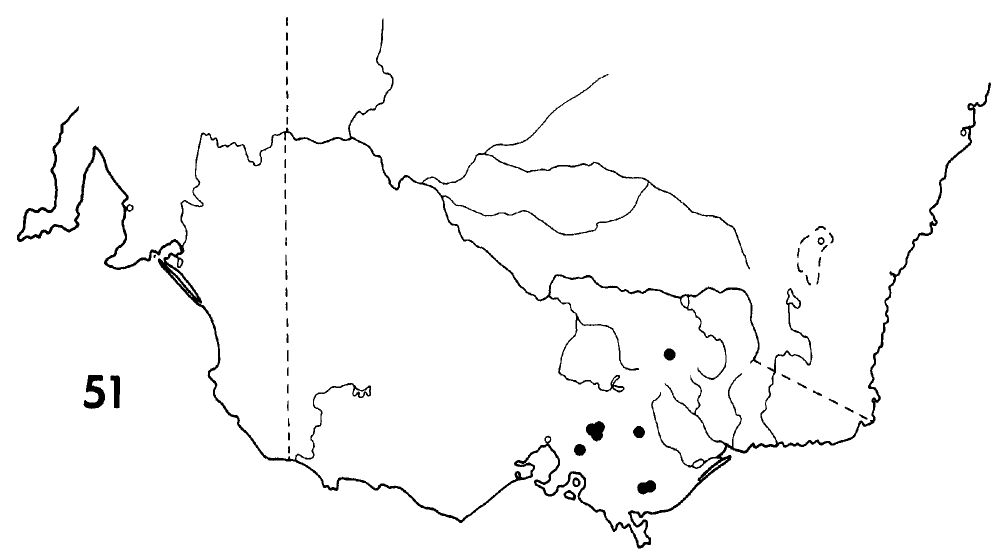

Fig. 51. Victoria, Australia, with dots showing locality records for Glypholoma rotundulum.

various combinations of these), with the normal spots obscured in these regions. Some individuals with very small yellow spots on the pronotal margins, the maximum being an anterior paramedial pair, a lateral pair, a posterior paramedial pair, and a posterior lateral pair. Dorsal surface of body with minute to short setae (as well as macrosetae on elytra), tibiae and tarsi fairly densely setose. Length: $2.5 \pm 0.2 \mathrm{~mm}(2.1-3.0)$; width: $1.2 \pm 0.1 \mathrm{~mm}(1.0-1.3)(\mathrm{N}=18)$.

Head capsule similar to that of pustuliferum (fig. 58), but epistomal suture slightly arcuate medially, with short median stem. Antennal length about 1.2 times head width, first seven antennal segments without dense pubescence, antennal club three-segmented, slightly more abrupt than in pustuliferum (see fig. 55). Ocellar diameter about 0.08 times head width. Labrum slightly emarginate anteriorly. Maxillary palp with fourth segment about five times as long as third, its inner side slightly swollen so that fourth segment at middle is about half again as wide as third segment.

Pronotum as in fig. 5, evenly convex except for a broad shallow depression near each posterior angle, lateral margins acute anteriorly, explanate posteriorly. Prosternum coarsely punctate, with microsculpture and median longitudinal carina. Mesosternum (see figs. 35,37 ) with dense microsculpture except on the raised pentagonal mesosternal process, cavities for reception of procoxae about three-fourths the length of the mesosternum, mesosternal 
process extending about four-ninths of the way between mesocoxae. Metasternum convex, without microsculpture but with large punctures containing very short setae, antecoxal sutures short, extending only one-fifth the width of the metasternum. Protibia setose, slightly less spinose than that of pustuliferum, meso- and metatibia slightly more spinose than protibia. Hind tarsus slightly less than six-tenths as long as hind tibia, fifth segment of hind tarsus half as long as first four together. Empodial setae longer than tarsal claws.

Elytral striae impressed between punctures, intervals minutely punctate and with very short setae, in addition to the usual macrosetae on alternate intervals (see fig. 29). Pale spots (but not pustules) anterior and adjacent to macrosetae. Angle formed by elytral apices at suture slightly greater than $180^{\circ}$ (concave posteriorly). Wings greatly reduced in nearly all specimens seen, only extending over tergite 2 , and not folded at rest (see figs. 37,41 ), very rarely fully or almost fully developed; anal flap present.

Abdomen with tergites 4 to 8 well-sclerotized, spiracles located in tergites of segments 5 to 8 , at edge of tergite 4; paratergites clearly present and distinct on segments 4 to 6 , sutures between sternite and paratergites lacking on segment 3; segment 7 with sutures between sternite and paratergites fading out posteriorly. Tergite 4 with small paired patches of medially-directed microtrichia (see fig. 41), tergite 5 with or without even smaller transverse patches of same near posterior edge. Transverse fold on sternite 3 about one-half width of sternite. Sternite 8 with anterior projection as in fig. 65 .

Male: Spatulate setae on protarsus as in fig. 25, five pairs on first segment, two pairs each on second and third segments, on first two segments of mesotarsus, similarly to fig. 39 , but with five on the first segment and two on the second; genital segment and aedeagus as in figs. 74, 75, 78, 79.

Female: Genitalia very similar to those of $G$. pustuliferum, distal gonocoxites relatively slightly thicker.

Distribution: see map (fig. 51).

Holotype $\left(\delta^{*}\right)$ : Australia: Victoria: Belgrave, F. E. Wilson, 22-5-29/Fallen leaves/F. E. Wilson Collection [NMVM].

Paratypes: AUSTRALIA: Victoria: Warburton, F. E. Wilson, 4080 feet/in tussocks/F. E. Wilson Collection (3 $\delta$ ) [NMVM]; Mt. Baw Baw, summit, etc., Mar. '58, Darlington (1 $\left.0^{\prime}\right)$ [MCZ]; Warburton, Mt. Donna Buang, 1200 m, IV.28-V.7.1978, carrion traps, Nothofagus forest, S. B. Peck (79 o, 104 \%) [ANIC, ANMT, CAS, CNC, 

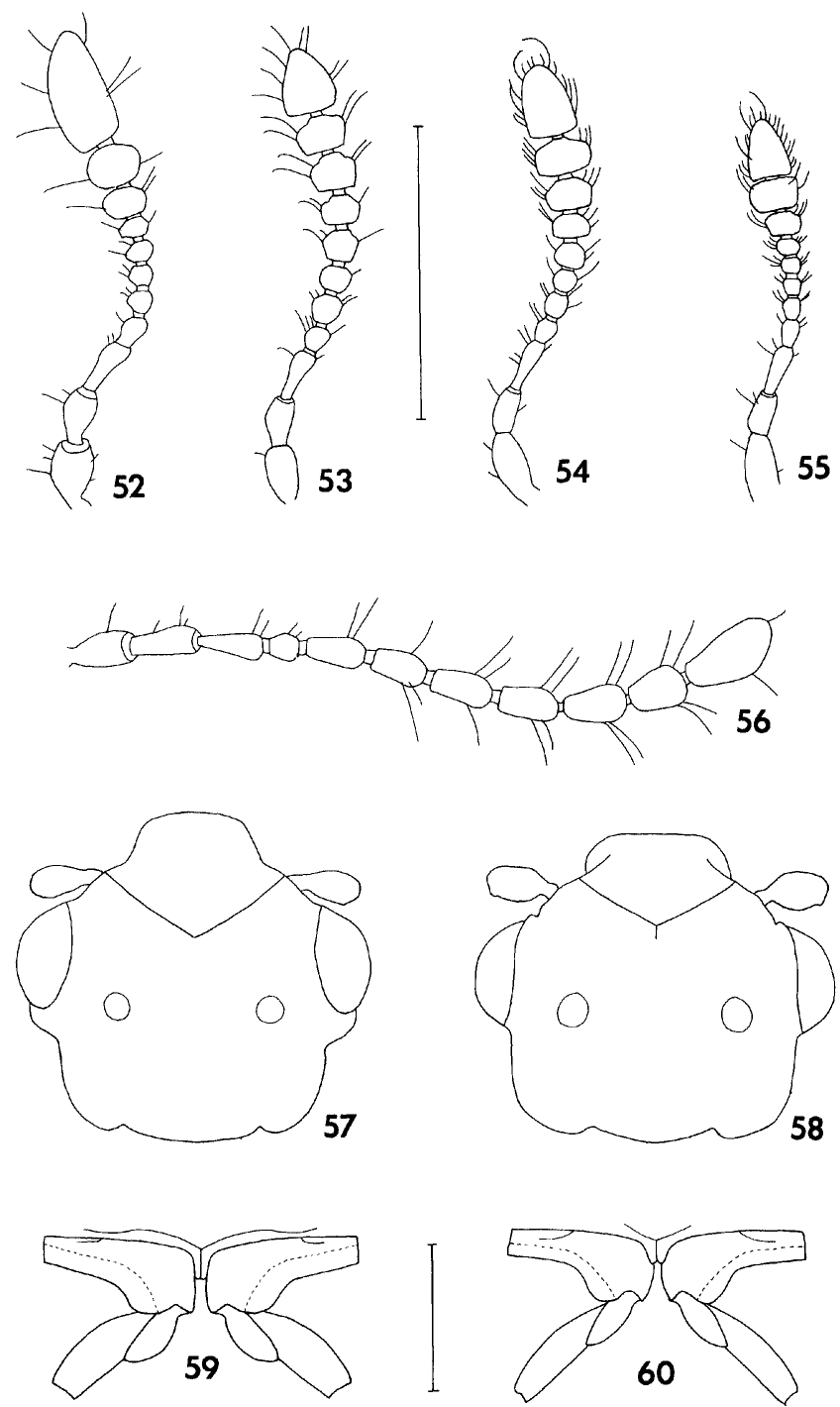

Figs. 52-60. Glypholoma spp. 52-56. Right antenna, dorsal view; 52, G. pecki; 53, G. temporale; 54, G. pustuliferum; 55, G. rotundulum; 56, G. tenuicorne. 57-58. Head, dorsal view; 57, G. temporale; 58. G. pustuliferum. 59-60. Metacoxae and metasternal antecoxal sutures; $59, G$. temporale; $60, G$. pustuliferum. Scale lines = $0.5 \mathrm{~mm}$; upper one applies to figs. 52-58, lower one to figs. 59-60. 

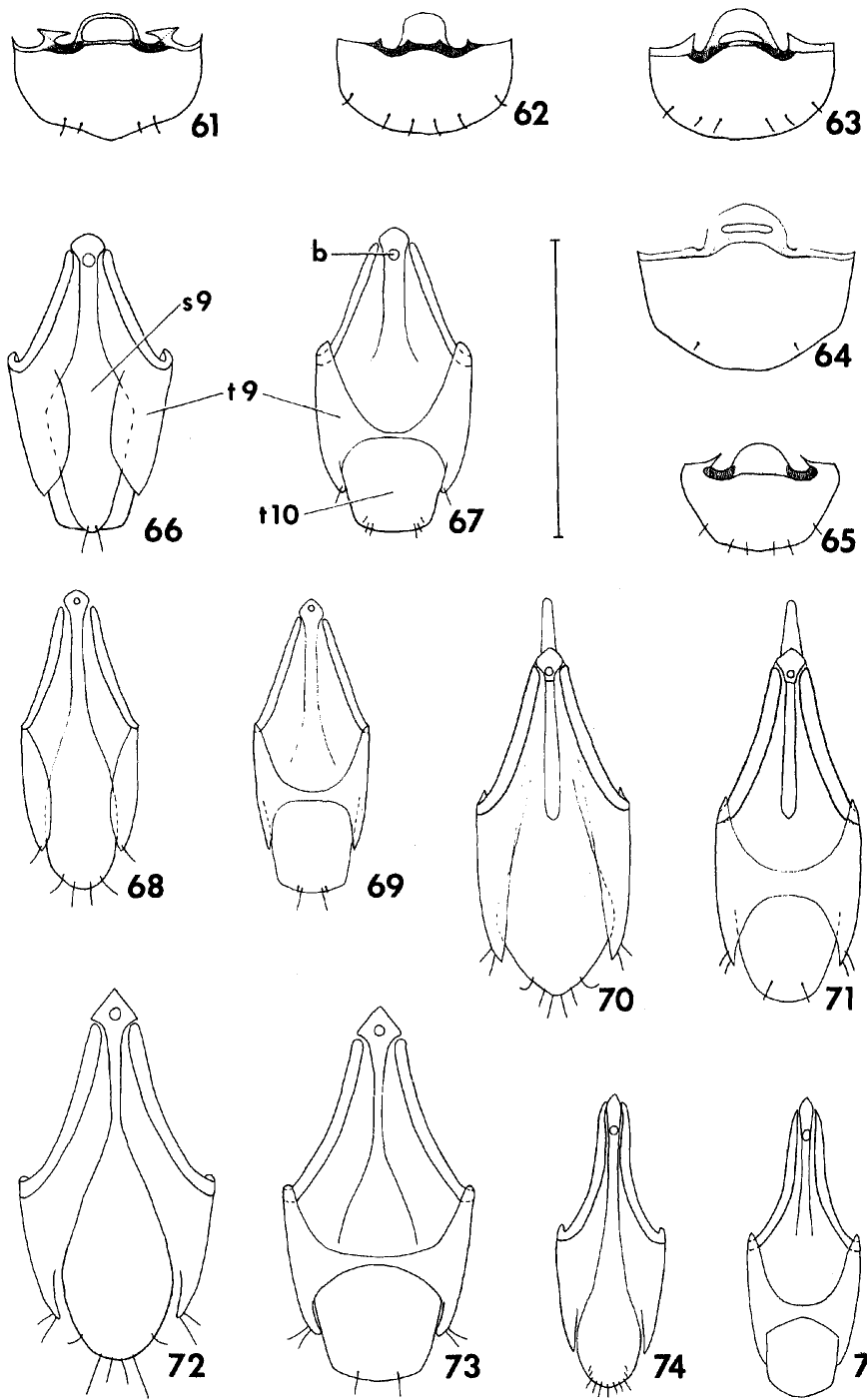

Figs. 61-75. Glypholoma spp. 61-65. Abdominal sternite 8, ventral view; 61, G. pustuliferum; 62, G. pecki; 63, G. temporale; $64, G$. tenuicorne; $65, G$. rotundulum. 66-75. Male genital segment, ventral and dorsal views, respectively; 66-67, G. pustuliferum; 68-69, G. pecki; 70-71, G. temporale; 72-73, G. tenuicorne; 74-75, G. rotundulum. $\mathrm{b}=$ internal cylindrical "button"; $\mathrm{s} 9=$ sternite $9 ; \mathrm{t} 9=$ tergite $9 ; \mathrm{t} 10=$ tergite 10 . Scale line $=0.5 \mathrm{~mm}$. 

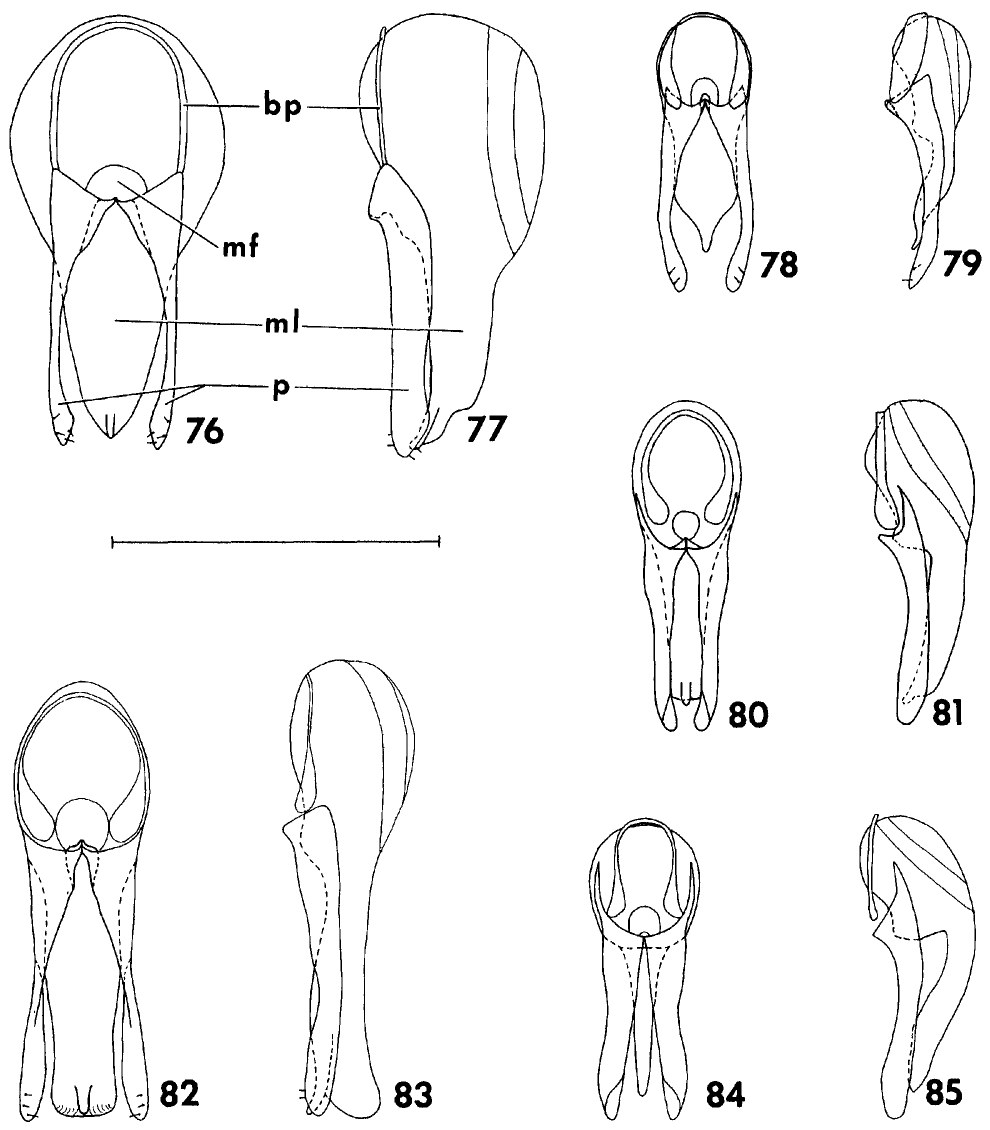

Figs. 76-85. Glypholoma spp., aedeagus (in situ), dorsal and right lateral views, respectively. 76-77, G. tenuicorne; 78-79, G. rotundulum; 80-81, G. pecki; 82-83, G. temporale; $84-85, G$. pustuliferum. $\mathrm{bp}=$ basal piece; $\mathrm{mf}=$ median foramen; $\mathrm{ml}=$ median lobe; $\mathrm{p}=$ paramere. Scale line $=0.5 \mathrm{~mm}$. 
FMNH, MCZ, NMVM, SBP]; Warburton, Acheron Gap, $750 \mathrm{~m}$, VI.27-30.1978, Ber.u.log bark Euc. + Notho., S. B. Peck (2 o , 6 \%) [SBP]; same locality, IV.28-V.7.1978, carrion trap, Nothofagus forest, S. B. Peck (4 $\left.\sigma^{*}\right)$ [ANMT]; Tara Valley N.P., $450 \mathrm{~m}$, V.10-17.1978, carrion traps, S. \& J. Peck (4 ơ , 8 \% ) [ANMT]; Bulga N.P., $550 \mathrm{~m}, \mathrm{~V} .10-17.1978$, carrion traps in Nothofagus ravine, S. \& J. Peck $\left(11 \delta^{*}, 12 \%\right)$ [ANIC, ANMT, CNC, SBP]; same locality, V.17.1978 Ber. fungi on logs and stumps, S. \& J. Peck (7 $\delta^{\star}, 5 \%$ ) [SBP]; Mt. Buffalo N.P., 1300 m, IV.22-26.1978 carrion trap, S. \& J. Peck (2 ¿ ) [ANMT]; same locality, 500 m, IV.24-27.1978, wet sclerophyll forest, creek: carrion, S. B. Peck (1 $q$ ) [MCZ]; Victoria? /ex C. Oke Collection, no locality $(2 \delta, 2 \uparrow)$ [NMVM].

Habitat: Ecological data are available for all but five of the 252 specimens of this species seen. Of these, 225 specimens were collected in carrion traps or at carrion (six collections), twelve from fungi on logs and stumps (one collection), eight under bark of Eucalyptus and Nothofagus logs (one collection), three in tussocks (one collection), and one among fallen leaves (presumably loose ground litter). Most of the specimens were collected in Nothofagus forest, and in general Glypholoma rotundulum seems to occur in habitats similar to those of $G$. pustuliferum, but nothing is known about the feeding habits of this species, either. These beetles seem to be notably cold-adapted. The largest collection (183 specimens) was taken in carrion traps set in snow-covered ground (S. B. Peck, pers. comm.), across which the flightless beetles must have walked.

Wing polymorphism: All specimens examined are brachypterous except the three from Mt. Buffalo, the northernmost recorded locality for the species. One of these specimens $\left(\delta^{*}\right)$ has fullydeveloped wings and the other two ( $\delta \&$ ) have wings sharply reduced beyond the costal hinge.

Etymology: The species name rotundulum (diminutive of rotundum, round) refers to the great convexity and small body size of the members of this species.

\section{DISCUSSION}

We believe that the five species here included in Glypholoma form a monophyletic group (in the strict, Hennigian sense) which can be defined on the basis of these characters which we presume to be uniquely derived or synapomorphic within Omaliinae: excavate 
hind coxae with "retractile" hind femora, each elytron with eleven more or less distinct striae, and male genital segment with a small "button" internally near the anterior end of sternite 9. Some of the species here included in Glypholoma have characteristics, such as the filiform antenna of tenuicorne and mesosternal structure of rotundulum, that might conventionally be used to justify the erection of new genera. Because the south temperate omaliine fauna is relatively poorly known, we feel that the use of a conservative generic concept is best at present, since this will possibly reduce the need for nomenclatural changes at the generic level as the full range of variation within the south temperate fauna becomes better known. A need for the creation of more genera may become apparent eventually; judgment of this is best reserved until at least a large proportion of the fauna (rather than the present fragments) is known.

Although not enough information is available to allow formulation of a complete phylogenetic hypothesis, a few comments can be made concerning probable relationships among the species of Glypholoma. Each species can be defined by an autapomorphous trait, as follows: tenuicorne, elytral striae not impressed between punctures; rotundulum, raised pentagonal mesosternal process; pecki, elongate antennal segment 11 ; temporale, bulging temples; and pustuliferum, coarsely punctured and rugose prosternum. All species but tenuicorne have clavate antennae (instead of filiform, which is presumably more primitive within Staphylinids) in common, and within this subgroup, pustuliferum and temporale share the apparently derived condition of raised pustules on the elytral intervals. No synapomorphies have been discovered yet which clarify the relationships among these four species any further. The availability of more material for detailed study of the three new South American species described in the present paper, and the discovery of immature stages or biological information for any species, might allow the discovery of additional synapomorphies and the development of a complete phylogenetic hypothesis.

The position of Glypholoma within the Omaliinae is somewhat ambiguous, largely because relationships within the subfamily as a whole are not very well worked out, especially the extra-Holarctic representatives of the subfamily. A majority of the characters distinguishing Glypholoma from most or all other Omaliinae are characters exhibiting plesiomorphic states in Glypholoma. This 
suggests, at least, that Glypholoma is a relatively primitive member of the subfamily and branched off early in the evolution of the Omaliinae. The close relationship of Glypholoma to the Holarctic Anthobium-group (viz., Anthobium, Camioleum, Deliphrum, Mathrilaeum, Olophrum) suggested by Scheerpeltz (1972) and Newton (1975) mainly on the basis of general habitus does not seem to be supported by more detailed evidence gathered to date. There are several characters for which the members of the Anthobium-group share what we believe are derived character states within the Omaliinae, and Glypholoma shows what we believe to be primitive character states. These characters appear in the Anthobium-group as follows: presence of a sharp post-ocular ridge, absence of the epistomal suture, gular sutures very close together or partly fused, presence of lateral foveae on the pronotum with internal pillars connecting dorsal and ventral surfaces of pronotum, and female genitalia with the proximal gonocoxites fused. We feel that this assemblage of differences constitutes strong evidence against a close relationship between Glypholoma and the Anthobium-group. Unfortunately any more precise statement concerning the placement and relationships of Glypholoma must await future clarification of the evolution and higher classification of the Omaliinae as a whole. In the meantime, tarsal, palpal, and mandibular characters dictate placement of Glypholoma in the heterogeneous tribe Anthophagini. If a familygroup name is eventually needed for Glypholoma, the name Glypholomini Jeannel 1962 is available.

The presence of two of the species of Glypholoma (pustuliferum and rotundulum) is strongly correlated with cool moist temperate forests dominated by Nothofagus; the other three species have been collected only within the Nothofagus zone of southern South America. The fact that each of the latter species is known only from a single small collection suggests that they may differ significantly from rotundulum and pustuliferum in their biology or ecological preferences. The disjunct southern temperate distribution of the genus is similar to those of some other isolated and apparently archaic groups of staphylinoids, some of whose ranges include New Zealand as well as southern South America and Australia. The occurrence of Glypholoma in New Zealand Nothofagus forests would not be wholly unexpected. 


\section{References Cited}

JEANNEL, R.

1962. Les Silphidae, Leiodidae, Camiaridae et Catopidae de la Paléantarctide Occidentale. Biol. de l'Amér. Aust. 1: 481-525.

KLINGER, R. AND U. MASChWITZ

1977. The defensive gland of Omaliinae (Coleoptera: Staphylinidae). I. Gross morphology of the gland and identification of the scent of Eusphalerum longipenne Erichson. J. Chem. Ecol. 3(4): 401-410.

Newton, A. F.

1975. The systematic position of Glypholoma Jeannel, with a new synonymy SCHEERELTZ, $O$. (Coleoptera: Silphidae, Staphylinidae). Psyche 82(1): 53-58.

1972. Wissenschaftliche Ergebnisse der Studienreise von Gy. Topál nach Sudwest-Argentinien (Coleoptera: Staphylinidae). Folia Ent. Hung. 25, Suppl., 268 pp., 5 pl.

SZYMCZAKowSKI, W.

1976. Silphidae, Leiodidae, Catopidae et Colonidae (Coleoptera) du Parc National du Nahuel Huapi en Argentine. Polskie Pismo Entom. 46: 423-438. 

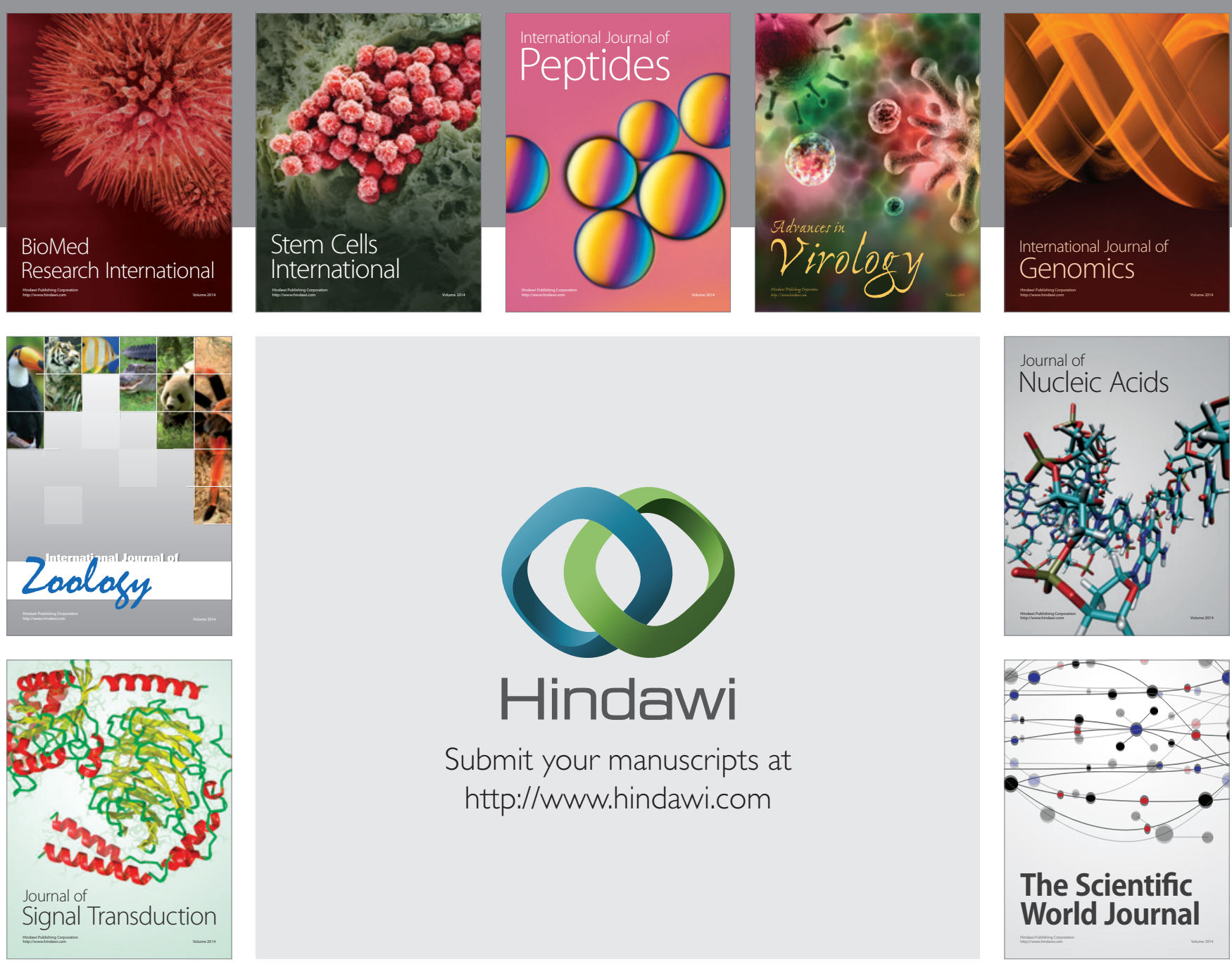

Submit your manuscripts at

http://www.hindawi.com
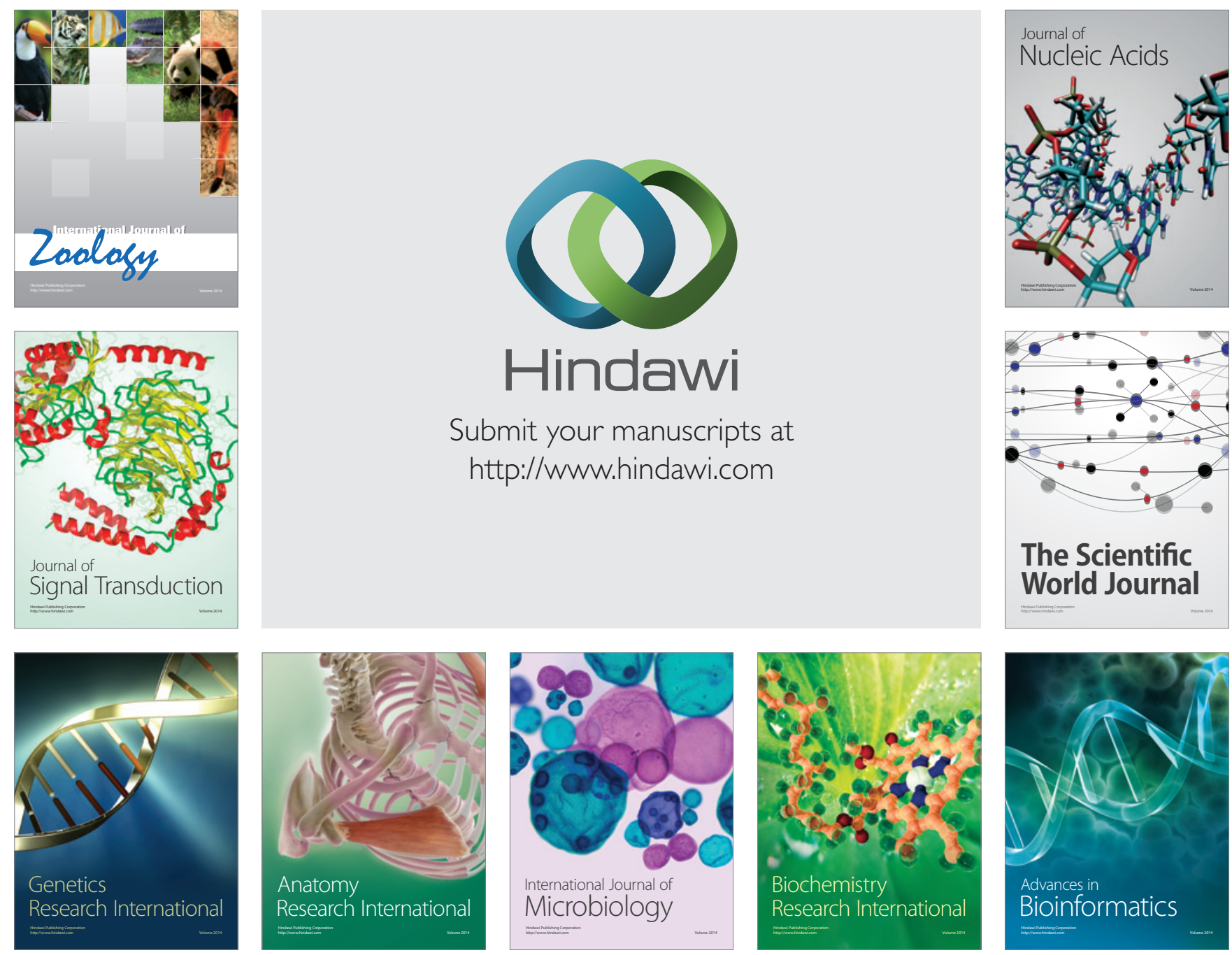

The Scientific World Journal
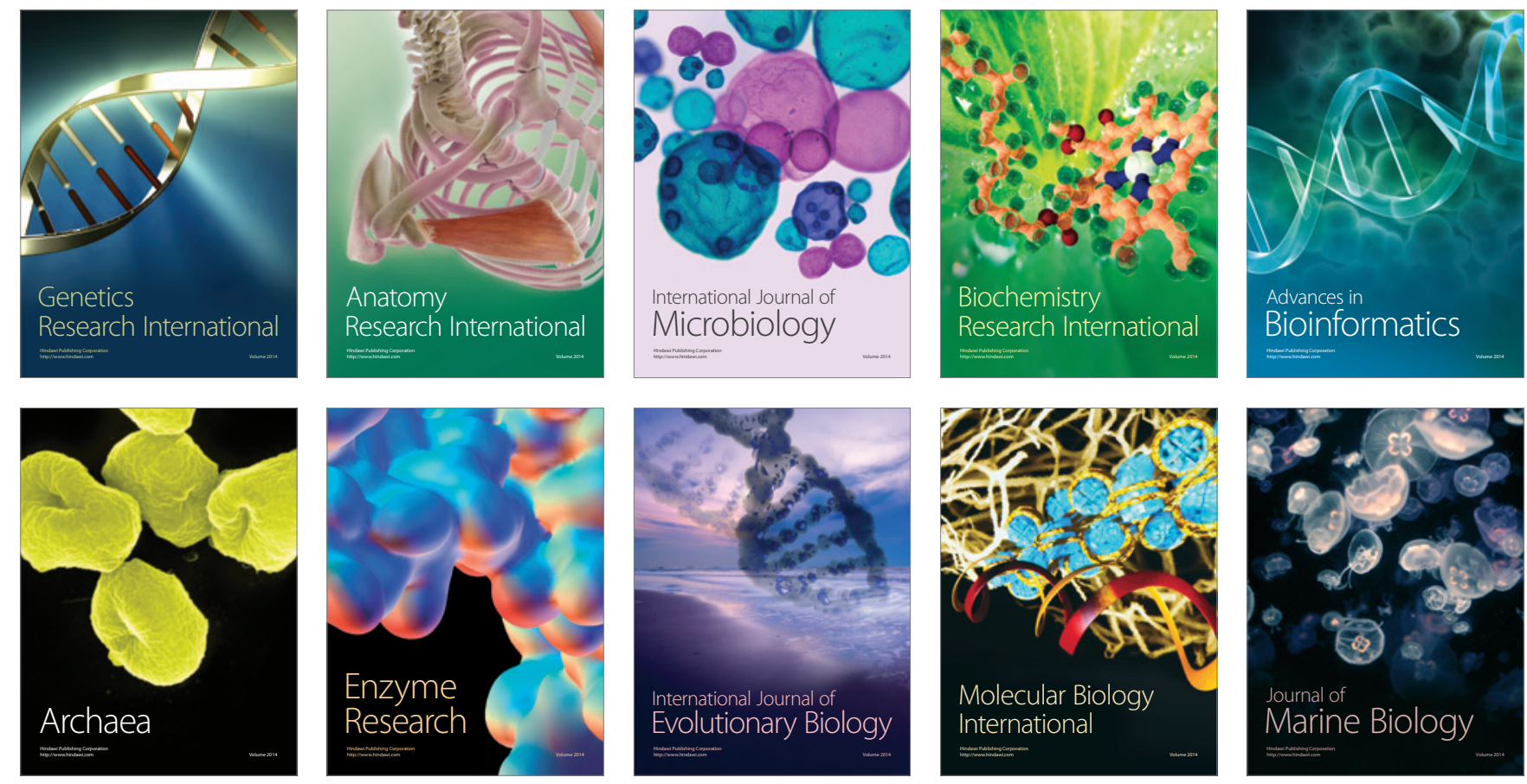